\title{
Reducing burden from respiratory infections in refugees and immigrants: a systematic review of interventions in OECD, EU, EEA and EU-applicant countries
}

Jan-Frederic Lambert ${ }^{1,2^{*}}$ (D, Katarina Stete ${ }^{1}$, James Balmford ${ }^{2}$, Annabelle Bockey ${ }^{1}$, Winfried Kern ${ }^{1}$, Siegbert Rieg ${ }^{1}$, Martin Boeker ${ }^{2 \dagger}$ and Berit Lange ${ }^{1,3+}$

\begin{abstract}
Background: Respiratory diseases are a major reason for refugees and other immigrants seeking health care in countries of arrival. The burden of respiratory diseases in refugees is exacerbated by sometimes poor living conditions characterised by crowding in mass accommodations and basic living portals. The lack of synthesised evidence and guideline-relevant information to reduce morbidity and mortality from respiratory infections endangers this population.

Methods: A systematic review of all controlled and observational studies assessing interventions targeting the treatment, diagnosis and management of respiratory infections in refugees and immigrants in OECD, EU, EEA and EUapplicant countries published between 2000 and 2019 in MEDLINE, CINAHL, PSYNDEX and the Web of Science.

Results: Nine of 5779 identified unique records met our eligibility criteria. Seven studies reported an increase in vaccine coverage from 2 to $52 \%$ after educational multilingual interventions for respiratory-related childhood diseases (4 studies) and for influenza (5 studies). There was limited evidence in one study that hand sanitiser reduced rates of upper respiratory infections and when provided together with face masks also the rates of influenza-like-illness in a hard to reach migrant neighbourhood. In outbreak situations of vaccine-preventable diseases, secondary cases and outbreak hazards were reduced by general vaccination strategies early after arrival but not by serological testing after exposure ( 1 study). We identified evidence gaps regarding interventions assessing housing standards, reducing burden of bacterial pneumonia and implementation of operational standards in refugee care and reception centres.

Conclusions: Multilingual health literacy interventions should be considered to increase uptake of vaccinations in refugees and immigrants. Immediate vaccinations upon arrival at refugee housings may reduce secondary infections and outbreaks. Well-designed controlled studies on housing and operational standards in refugee and immigrant populations early after arrival as well as adequate ways to gain informed consent for early vaccinations in mass housings is required to inform guidelines.
\end{abstract}

\footnotetext{
*Correspondence: F-lambert@web.de

${ }^{\dagger}$ Martin Boeker and Berit Lange contributed equally to this work

${ }^{1}$ Division of Infectious Diseases, Department of Medicine II, Medical

Center and Faculty of Medicine, University of Freiburg, Hugstetter Straße

55, 79106 Freiburg im Breisgau, DE, Germany

Full list of author information is available at the end of the article
} original author(s) and the source, provide a link to the Creative Commons licence, and indicate if changes were made. The images or other third party material in this article are included in the article's Creative Commons licence, unless indicated otherwise in a credit line to the material. If material is not included in the article's Creative Commons licence and your intended use is not permitted by statutory regulation or exceeds the permitted use, you will need to obtain permission directly from the copyright holder. To view a copy of this licence, visit http://creativecommons.org/licenses/by/4.0/ The Creative Commons Public Domain Dedication waiver (http//creativeco mmons.org/publicdomain/zero/1.0/) applies to the data made available in this article, unless otherwise stated in a credit line to the data. 
Keywords: Respiratory infections, Vaccination, Hygiene, Health literacy, Early interventions, Refugees, Migrants

\section{Background}

Worldwide, more than 60 million people were fleeing from war, violence, climate catastrophes, human rights violations and other circumstances at the end of 2017 [1]. Difficult living conditions, the context of having fled from hardship and cultural and language barriers can limit health care access and uptake, as well as result in missed opportunities for prevention, vaccination and treatment $[2,3]$.

Respiratory infections are a major reason why refugees and immigrants seek healthcare $[4,5]$. There is agreement that refugees and asylum seekers are not a notable source of transmission of respiratory disease to the general population [5-7]. Refugees and asylum seekers often are exposed to difficult living and housing conditions in sometimes improvised camps, shelters, and reception centres especially during the period of travel after forced migration, but also during the first months after arrival. In some communities not only refugees but also other immigrants may experience similar conditions due to crowded households, missing financial resources, unsanitary housings, and a lack of hygiene. Whenever talking in general about this population we therefore use the term "refugees and immigrants". However, due to these difficult living and housing conditions refugees and immigrants are not only at higher risk of respiratory infections [8], but also at higher risk of critical illness from vaccine preventable diseases [9] than non-migrant populations. This makes respiratory tract-related infections and vaccine-preventable diseases particularly important health issues in this population $[4,4,8,10-12]$.

To our knowledge no specific guidelines on reducing the overall burden of respiratory infectious diseases in refugees and immigrants exists. Instead national guidelines mostly focus on vaccine-preventable diseases not always specifically mentioning refugees and immigrants. Also, there is little consensus across different guidelines on which strategies should be applied [13-21]. There is a lack of specific guidelines targeting the management of respiratory infections as well as guidelines specifically aiming on refugee and immigrant populations (see Table 1).

Several recent reviews have criticised national screening guidelines as too restrictive, focussed on single diseases [22] and failing to cover the targeted populations $[4,22,23]$, failing to provide information on how to improve screening and treatment coverage and completion [23], and being insufficiently based on evidence and evidence synthesis [24] (see Table 2). Previous studies of refugee and immigrant populations have mainly been concerned with screening and treatment strategies, as well as the cost-effectiveness of tuberculosis prevention in immigrants from high to lower-incidence regions [2527]. Despite prevalence assessments of disease spectrums in migrant and refugee health and evaluations of implemented screening strategies[4, 5, 8], effective strategies and recommendations to reduce the burden of respiratory infections are lacking $[9,24,28-30]$. Healthcare providers often have insufficient training and are confronted with specific ethical, institutional and cultural issues as well as unfamiliar spectrums of diseases and symptoms [31-33]. Overviews and syntheses of evidence regarding effective interventions in refugees and immigrants are scarce, especially in industrial nations [24, 34, 35]. Yet evidence is urgently needed to inform recommendations for treatment, diagnostics, screening and effective prevention of infectious diseases $[22,28]$ in national and international guidelines.

The objective of this systematic review is to collect and synthesize evidence on the effect of interventions to diagnose, treat and manage respiratory-tract infections in refugees and immigrants in OECD, EU, EEA and EUapplicant countries.

\section{Methods}

This review was carried out in accordance with the PRISMA Statement [36] and the Cochrane Handbook [37, 38]. (PROSPERO: CRD42018074338) [39]. A completed PRISMA checklist is provided as Additional file.

\section{Eligibility for inclusion}

We included controlled studies (including non-randomised intervention studies and longitudinal studies with pre-test/post-test designs) published between 1 January 2000 and 1 October 2019. Study populations were refugees [40], asylum seekers [40] or immigrant hardto-reach populations (e.g. Sinti and Roma, sex workers, drug abusers, prisoners, homeless people and people living with HIV $[29,41])$. As previously mentioned, we use the term "refugees and immigrants" whenever talking about this population in general. Place of intervention was a member country of the OECD [42], the European Union [43, 44], the European Economic Area (EEA) [45] or an European Union applicant country [46] (For full list of included countries see Additional file 1). Included were interventions to reduce incidence, prevalence, mortality, delay to diagnosis and treatment and transmission from respiratory infections, including lower 


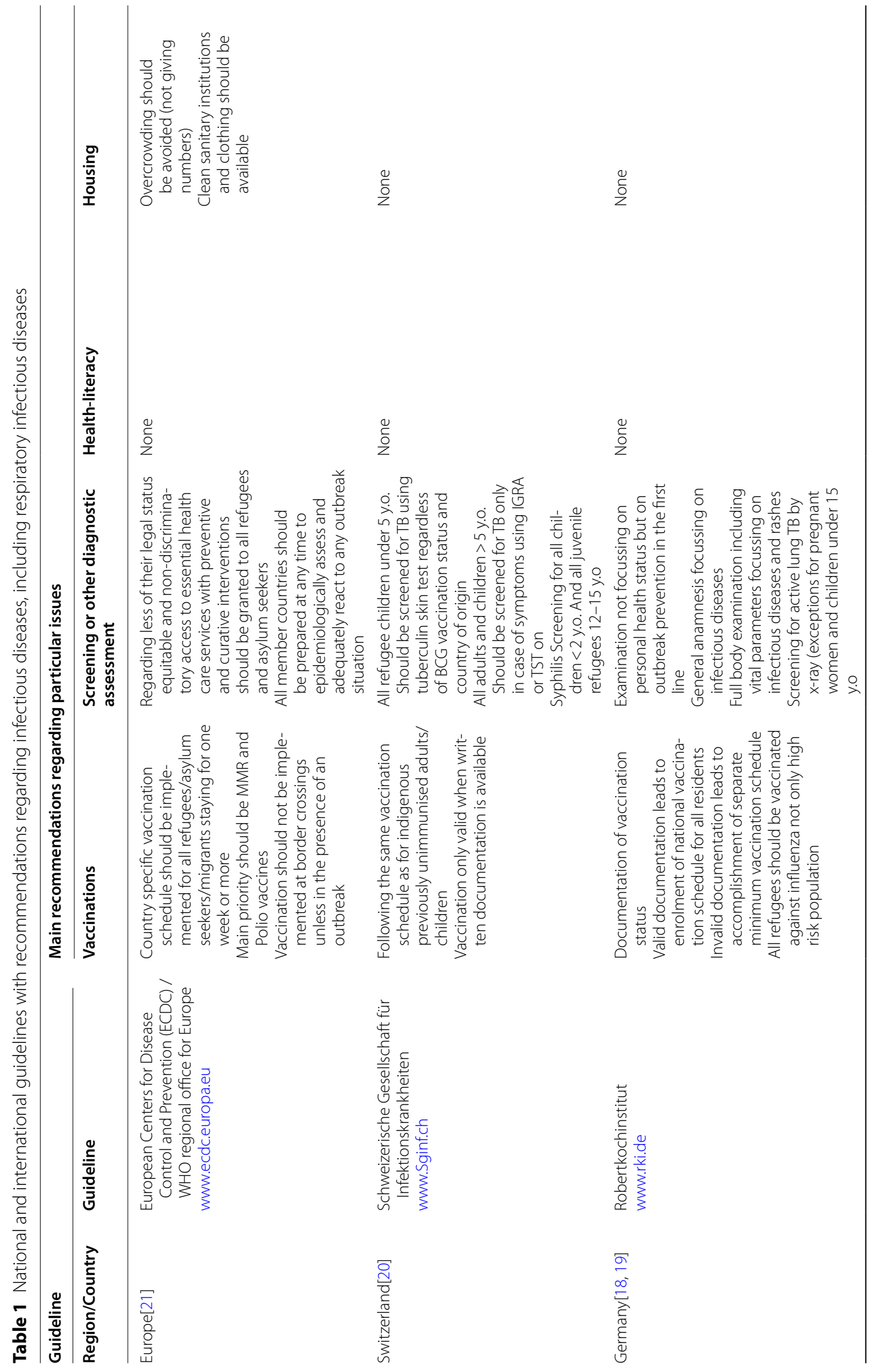




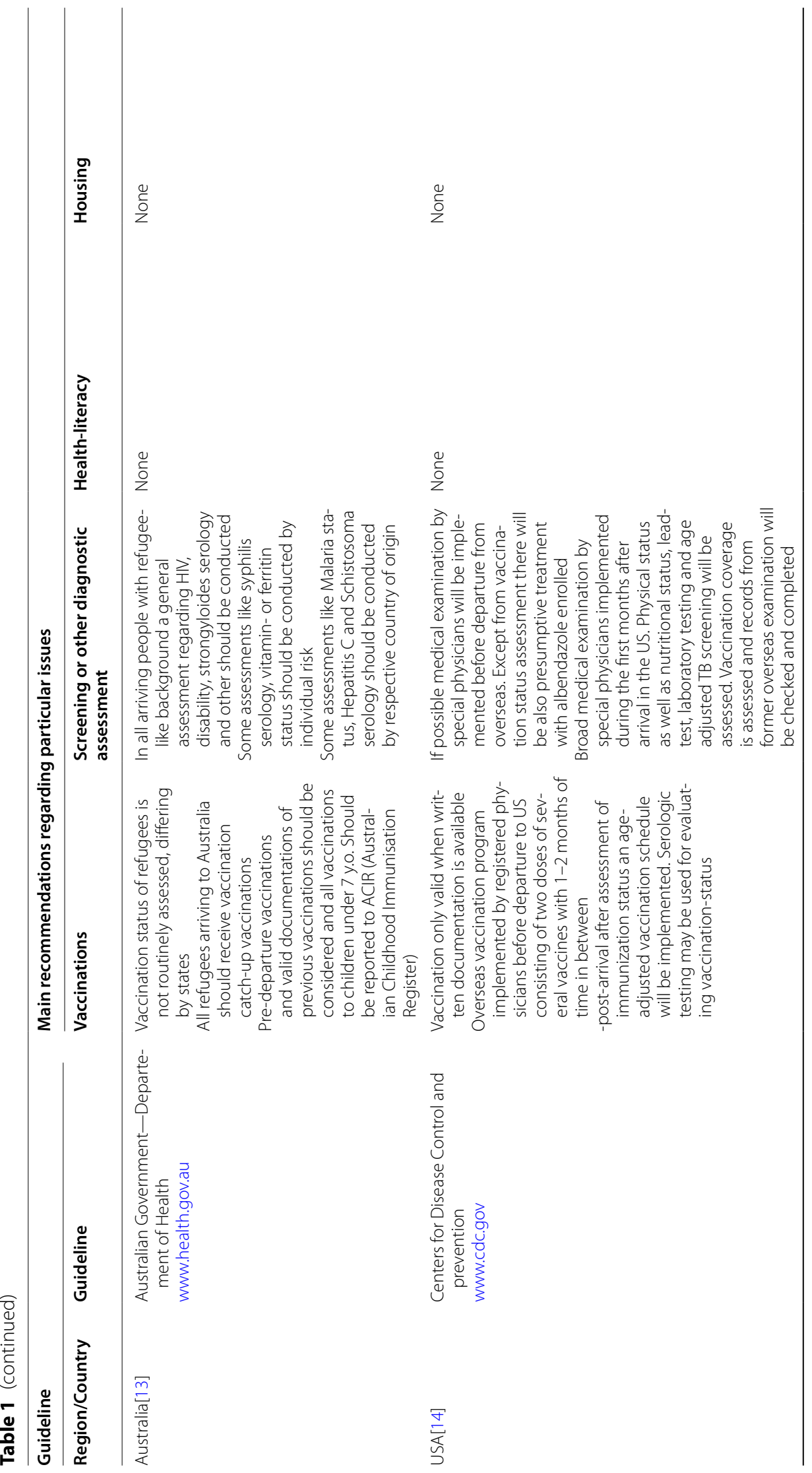




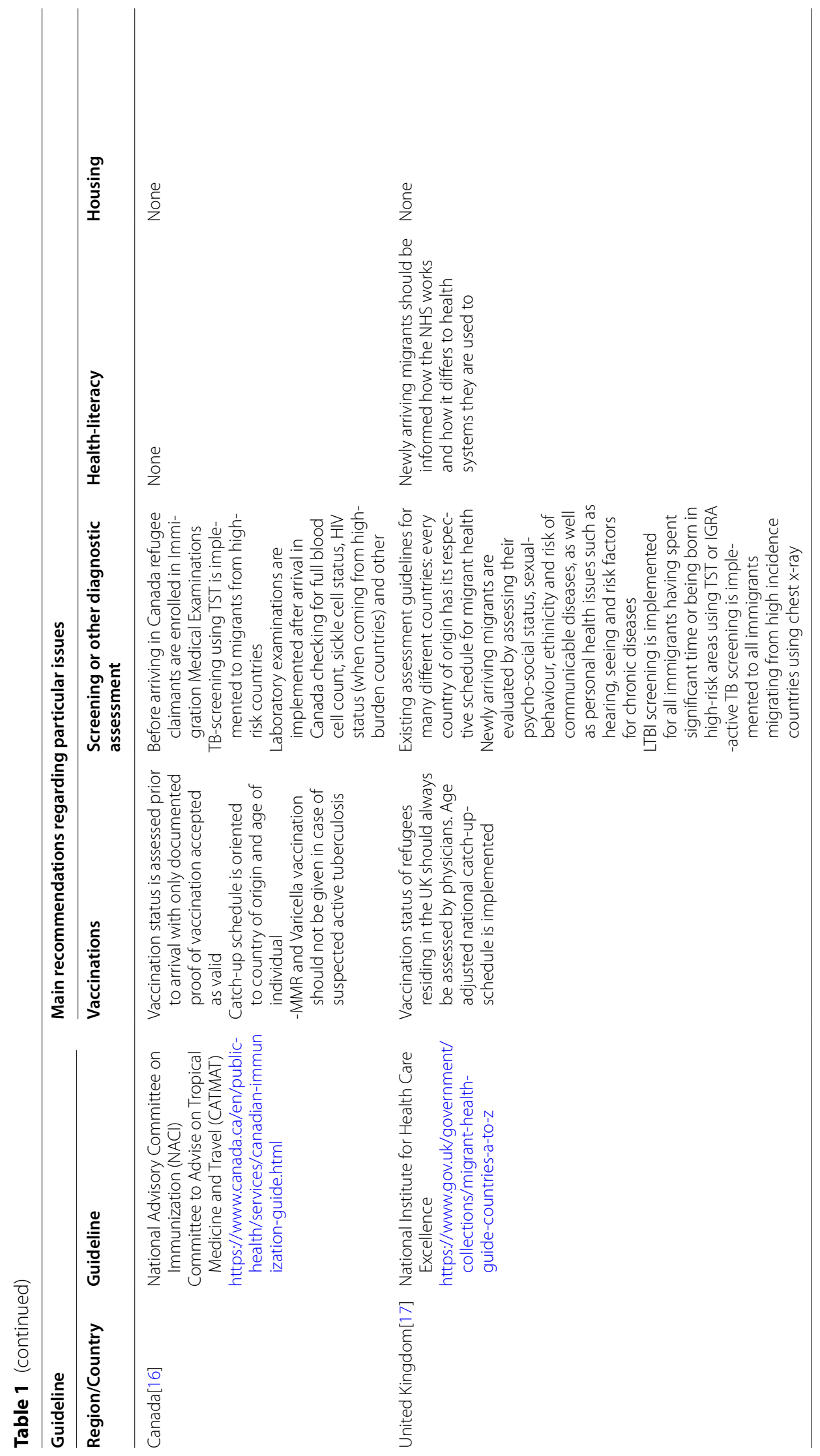


Lambert et al. BMC Infect Dis $\quad$ (2021) 21:872

Page 6 of 25

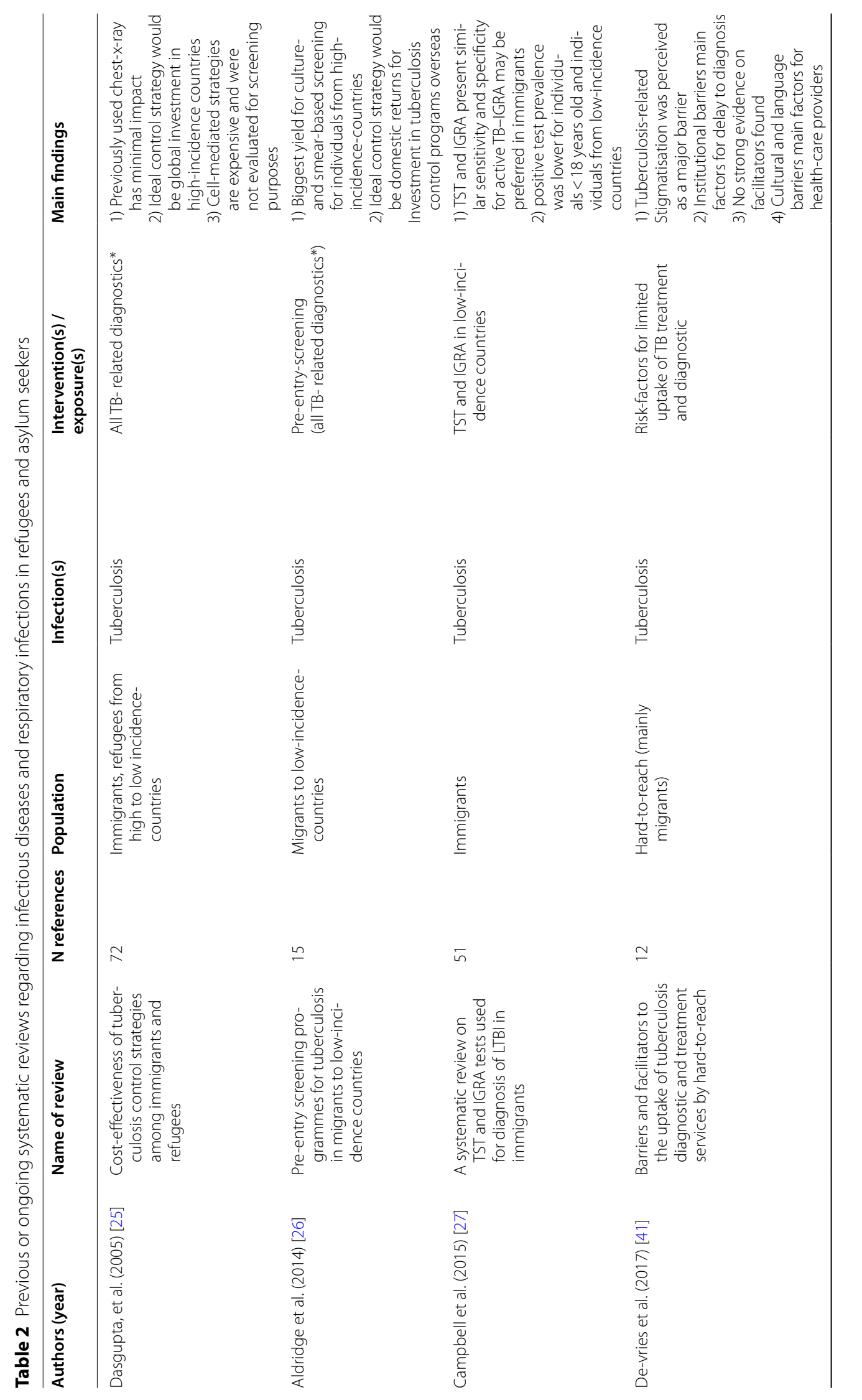




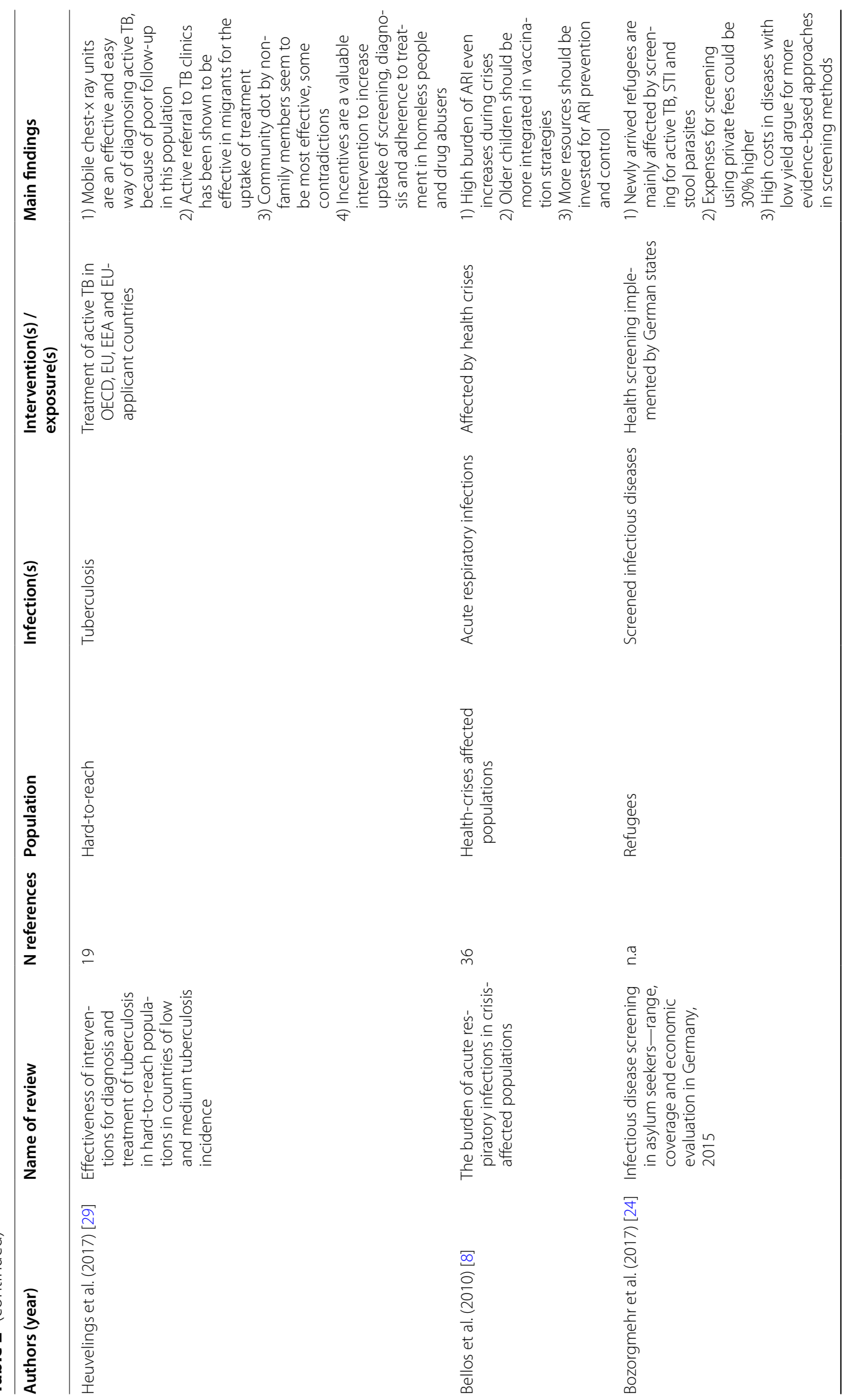




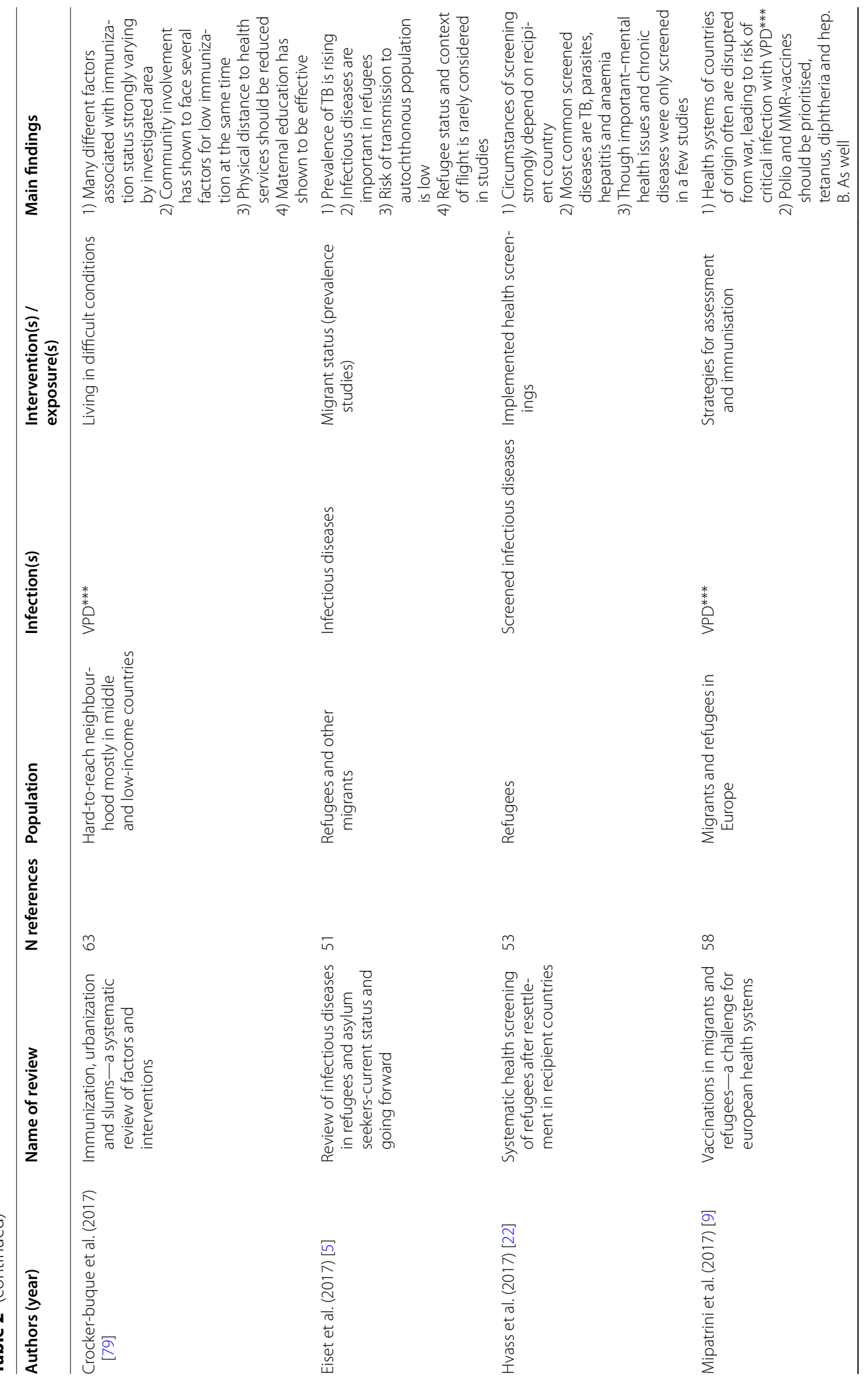




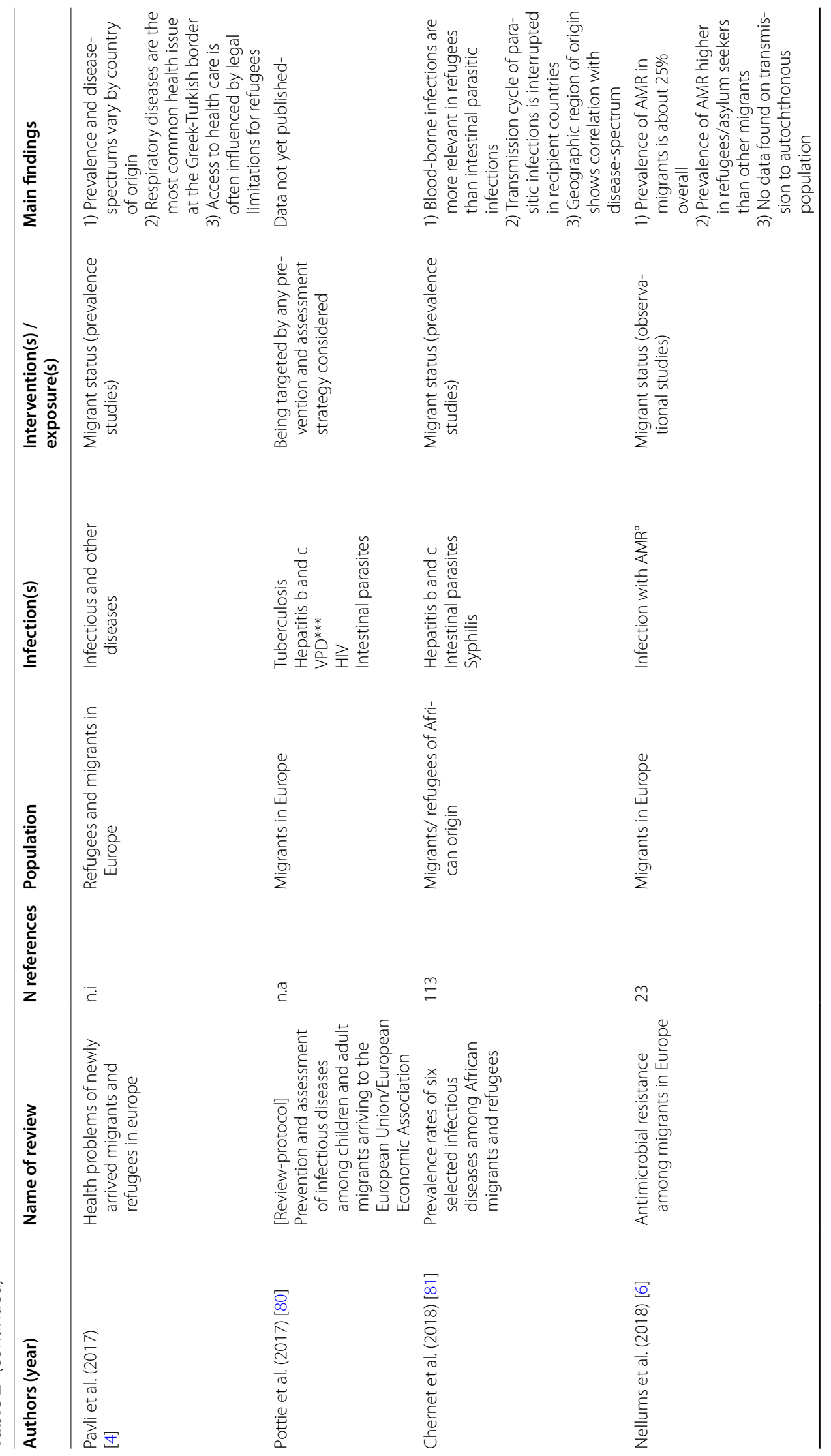




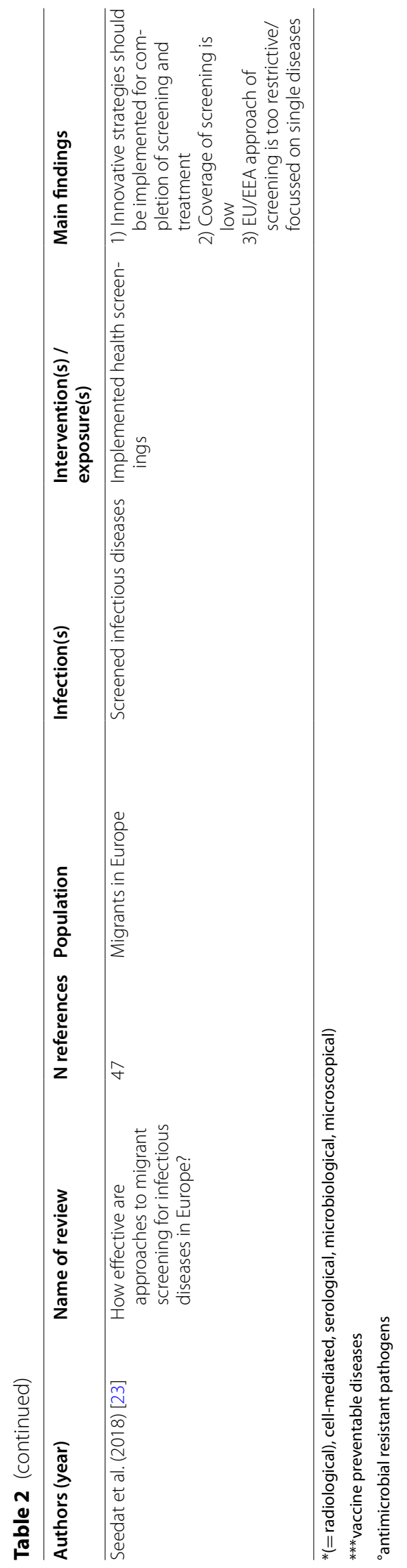


and upper respiratory infections of unknown aetiology, acute respiratory infections and respiratory infections with pathogens listed in the PICOS table (Table 3). Also included were interventions to improve vaccination coverage for respiratory-related vaccine-preventable diseases. We excluded interventions to reduce tuberculosis incidence due to the existence of several recently-published systematic reviews [25-27, 29, 41]. Studies with any type of individual- or group-level interventions were included: outbreak prevention, any type of vaccination campaign, health literacy interventions, pharmaceutical and non-pharmaceutical prevention and treatment strategies, housing interventions and local health care arrangements.

Outcomes were change in diseases incidence, prevalence or mortality, delay to diagnosis or treatment, transmission rates, number of secondary cases and vaccination coverage.

\section{Search strategy, study selection and data collection}

The database search was conducted following the Cochrane Collaboration guideline for systematic literature searches $[47,48]$. The following databases were searched in June 2017. The search was updated in May 2018 and October 2019:

- MEDLINE ${ }^{\circledR}$ using OvidSP (including: Ovid MEDLINE $^{\circledR}$ Epub Ahead of Print, In-Process \& NonIndexed Citations, Ovid MEDLINE ${ }^{\circledR}$ Daily)

- Web of Science by Clarivate Analytics using All Databases

- CINAHL using EBSCOhost

- PSYNDEX using EBSCOhost.

The search terms in the literature review included specific terms for respiratory infections, unspecific terms for infections and inflammation in general, terms for anatomic and topographic localisations, and terms for refugees and immigrants. The Medline ${ }^{\circledR}$ search was complemented by a Mesh Term search. The full search strategy can be found in Additional file 3.

References were screened by title and abstract by two reviewers (JFL and $A B$ ) independently, consensus was reached via consultation with a third reviewer (BL). For all selected abstracts full texts were obtained. We extracted information on study characteristics, study population, study design and outcome measures. In cases of incomplete or inconsistent data, authors were contacted.

Interrater agreement was calculated with kappa-statistics using the respective decisions whether to include or to exclude a study of the two reviewers J-F L and AB.
Our used data collection form is provided in Additional file 2 .

After extraction, data was summarised and represented in tabular form by outcomes and outcome measures: Incidence rate, outbreak measures in number of secondary cases per exposed individual and vaccination coverage as percentage of being vaccinated. Further outcome measures were not found, i.e. mortality rate, delay to diagnosis and treatment. Whenever possible, we calculated risk or rate ratios comparing intervention and control groups to achieve better comparability.

\section{Risk of bias assessment}

Risk of bias assessment was carried out using the ROBINS-I tool for cohort-style non-randomised trials of interventions for all included non-randomised trials [49] and using RoB2.0 for all included randomised controlled trials [50]. Risk of bias across studies was evaluated for publication and language bias and following the GRADE recommendations in the range of outcome subgroups across studies [51-55].

\section{Results}

\section{Study Selection and characteristics}

After manual deduplication 5779 of 10,242 abstracts remained for screening. After title and abstract screening 105 full texts were assessed of which 9 studies were included in the review. Inter-reviewer reliability was high. The calculated kappa was $=1$. While the actual decisions whether to include or exclude a study were the same in $100 \%$ of cases $(\mathrm{kappa}=1)$, only in $96 \%$ the reasons for these decisions were the same. The PRISMA flowchart is displayed in Fig. 1.

\section{Results of individual studies}

(See Table 4 and 5).

While using the term "refugees and immigrants" whenever talking in general about the targeted populations in this review we used the respective expression of the respective study when narrating the individual results.

\section{Influenza vaccination/interest in vaccination informational campaigns}

Three studies assessed influenza vaccination in hardto-reach neighbourhoods in New York City with an immigrant proportion of more than 70\% [56-58]. Each evaluated multilingual information campaigns in various forms such as comic strips, informational talks, and community events responding to common myths about vaccinations and advising on locations of free vaccination clinics. Three different outcomes have been measured. The interest in getting vaccinated against influenza [58] increased by $14 \%$ post-intervention compared to 
Table 3 PICOS table

\begin{tabular}{|c|c|c|c|c|}
\hline P & \multicolumn{4}{|c|}{$\begin{array}{l}\text { Refugees[40] } \\
\text { Asylum seekers[40] } \\
\text { Migrant hard-to-reach populations[41] } \\
\text { Living in the geographical territory of OECD[42], EU[43], EEA[45] and EU-applicant [46] countries }\end{array}$} \\
\hline I & \multicolumn{4}{|c|}{$\begin{array}{l}\text { All interventions targeting to lower incidence, prevalence, transmission, or mortality of one or more of the following respiratory infec- } \\
\text { tions: }\end{array}$} \\
\hline & Upper respiratory infections & Lower respiratory infections & Included edge-cases & Separate pathogens \\
\hline & $\begin{array}{l}\text { Sinusitis } \\
\text { Otitis } \\
\text { Stomatitis (+Herpes) } \\
\text { Catarrh } \\
\text { Laryngitis } \\
\text { Epiglottitis } \\
\text { Scarlet fever Rhinoscleroma } \\
\text { Nasopharyngitis } \\
\text { Rhinitis (+Coryza) } \\
\text { Diphtheria } \\
\text { Tonsillitis } \\
\text { Pharyngitis } \\
\text { Supraglottitis }\end{array}$ & $\begin{array}{l}\text { Pneumonia } \\
\text { Pseudo-Croup } \\
\text { Pleuritis } \\
\text { Empyema } \\
\text { Tracheitis } \\
\text { Bronchitis } \\
\text { Bronchiolitis (+obstr.) } \\
\text { Bronchopneumonia } \\
\text { Pleuropneumonia } \\
\text { Pertussis }\end{array}$ & $\begin{array}{l}\text { Abscesses: } \\
\text { Mediastinal } \\
\text { Peritonsillar } \\
\text { Retropharyngeal } \\
\text { Lung } \\
\text { Influenza } \\
\text { Mumps } \\
\text { Measles } \\
\text { Mononucleosis } \\
\text { Chickenpox }\end{array}$ & $\begin{array}{l}\text { Haemophilus } \\
\text { Measles virus } \\
\text { Influenza virus } \\
\text { EBV } \\
\text { RSV } \\
\text { Mumps virus } \\
\text { Varicella } \\
\text { Adenovirus } \\
\text { Pasteurella } \\
\text { C. diphtheriae } \\
\text { Pneumococcus } \\
\text { Bordetella } \\
\text { Legionellosis } \\
\text { Aspergillosis } \\
\text { Blastocysts } \\
\text { Blastomycosis } \\
\text { Histoplasmosis } \\
\text { Mycoplasma }\end{array}$ \\
\hline & \multicolumn{4}{|c|}{$\begin{array}{l}\text { These interventions include strategies for outbreak prevention, any type of vaccination campaign, local health care arrangements, } \\
\text { individual or institutional health literacy interventions pharmaceutical and non-pharmaceutical prevention and treatment strate- } \\
\text { gies and housing interventions }\end{array}$} \\
\hline C & \multicolumn{4}{|c|}{ Refugees and immigrants not (yet) having had access to the respective intervention } \\
\hline O & \multicolumn{4}{|c|}{$\begin{array}{l}\text { Effect of intervention measured by change of: } \\
\text { Incidence or prevalence of respiratory infections } \\
\text { Mortality of respiratory infections } \\
\text { Delay to diagnosis or delay to treatment of respiratory infections } \\
\text { Transmission and secondary case-numbers of respiratory infections }\end{array}$} \\
\hline S & \multicolumn{4}{|c|}{ All controlled studies including studies with pre-test/post-test-design and non-randomised intervention studies } \\
\hline
\end{tabular}

pre-intervention. The probability of a person vaccinated against influenza living in the same household as the respondent [56], increased by $10.2 \%$ pre-intervention compared to post-intervention. A randomised controlled study compared health literacy campaign with added non-pharmaceutical prevention strategies against influenza and upper respiratory infections [57]: one group (Group E) received only the informational campaign, another (Group 1) received additional alcohol-based hand sanitiser, and a third group (Group 2) received additional hand sanitiser and face masks. Influenza vaccination coverage improved in all groups after the intervention period by $19.7 \%$ in Group E, by $38.1 \%$ in Group 1 and by $21.1 \%$ in Group 2.

One study retrospectively evaluated the effect of the national vaccination campaigns against influenza in Spain in 2008/2009 and 2009/2010 [59]. There was no evidence of an increase in vaccination coverage in immigrants; the proportion of vaccinated immigrants increased insignificantly by $2.1 \%$ compared to the years before. We were unable to identify the main content of the campaign interventions. We found no official records of the interventions and received no answer to our requests for information.

In pregnant women of varying ethnicities in Seattle [60], influenza vaccination coverage increased by $27.2 \%$ post-intervention, which compares to data from the Pregnancy Risk Assessment Monitoring System (PRAMS) from separate studies [61-65]. The intervention in this study comprised three months of multi-language information and video material in the waiting room of a birthclinic as well as personal talks and "flu-packs" consisting of face masks, hand sanitiser and thermometers [60].

\section{Vaccination campaigns for respiratory tract-related childhood diseases}

Three studies evaluated different vaccination campaigns for respiratory tract-related childhood diseases [66-68]. One compared the effectiveness of two consecutive mass vaccination campaigns of governmental and non-governmental organisations against 8 antigens in recentlyarrived refugee children under 4 years of age fleeing from 


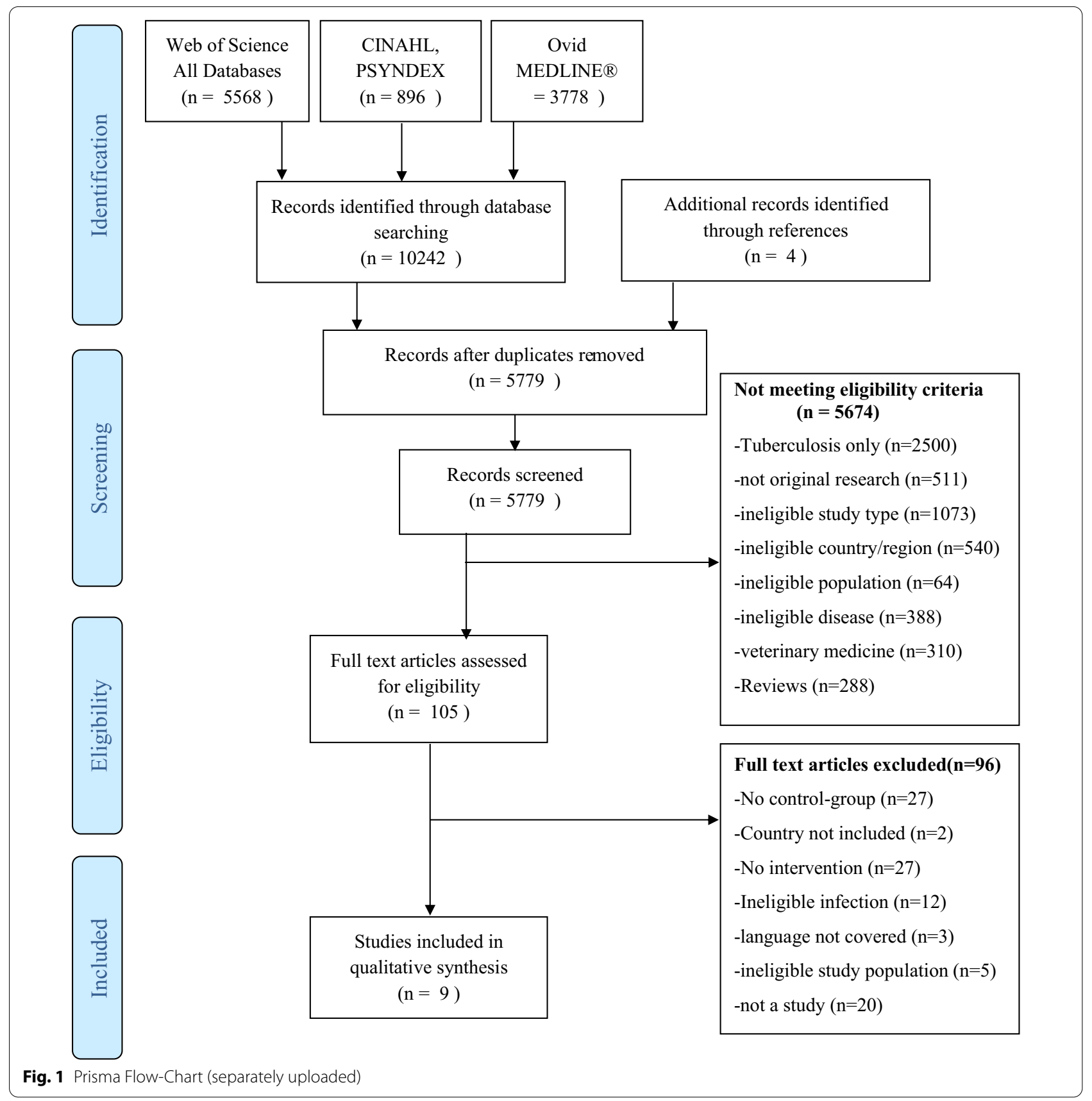

the Kosovo Crisis (1998/1999) in Macedonian refugee camps with high and low turnover [66], showing a benefit for more stable populations with less turnover: in a camp with high population turnover vaccination coverage rates dropped by $20 \%$ after the second campaign three weeks later, while in a stable population camp vaccination coverage stayed constant after both campaigns. Before the second mass vaccination weekly vaccination clinics were initiated in the respective camps.
In a second study the Ministry of Health in German reception centres implemented a vaccination campaign for MMR and DPPT which involved vaccine doses, informational material and interpreters to ensure informed consent in newly arrived refugees. The percentage of refugees with at least one vaccination increased by $26.8 \%$ compared to pre-intervention.

The third study evaluated the effect of the "keyperson" principle enhancing the effectiveness of a MMR vaccination campaign for children under 10 years of age 


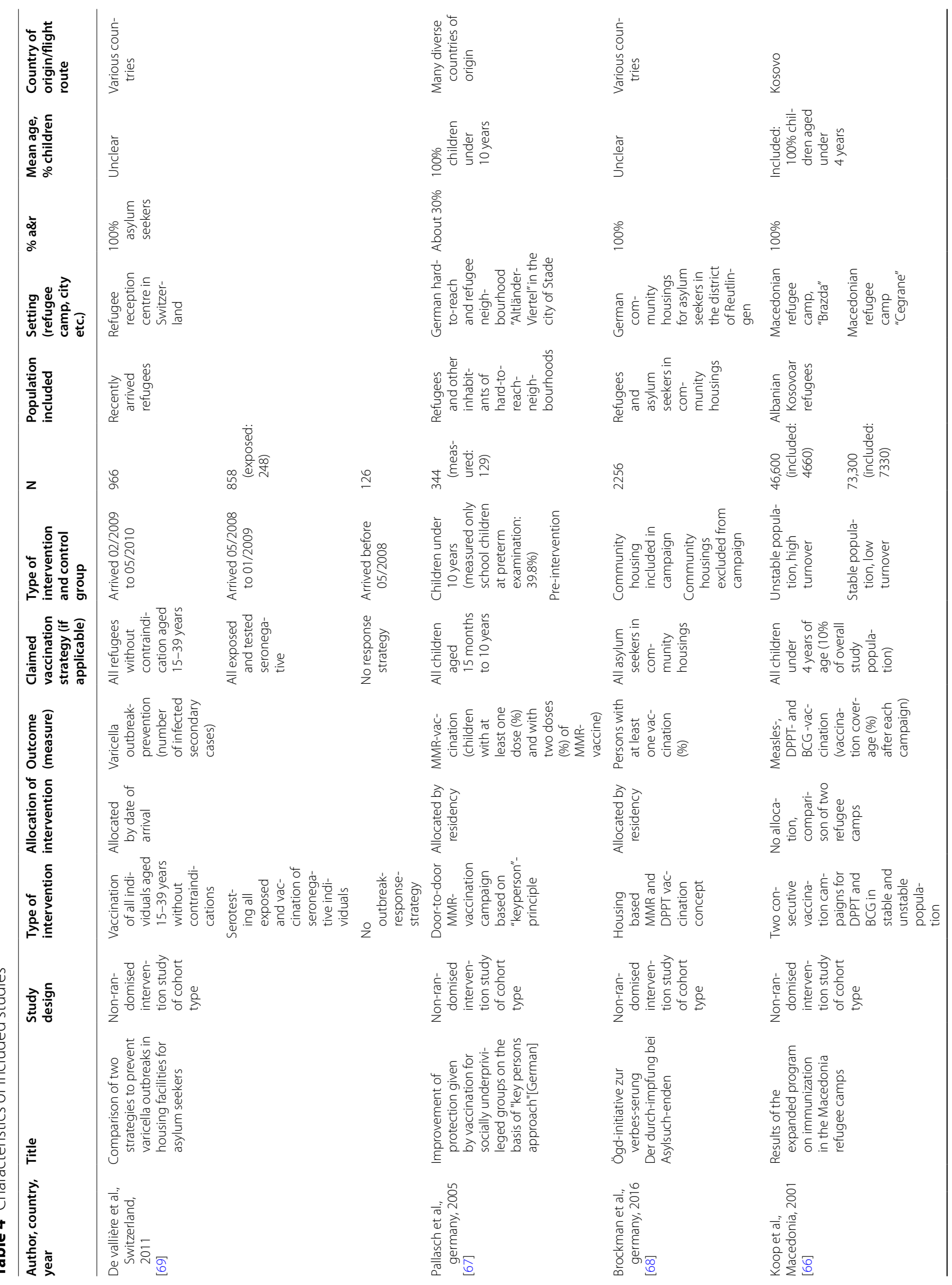




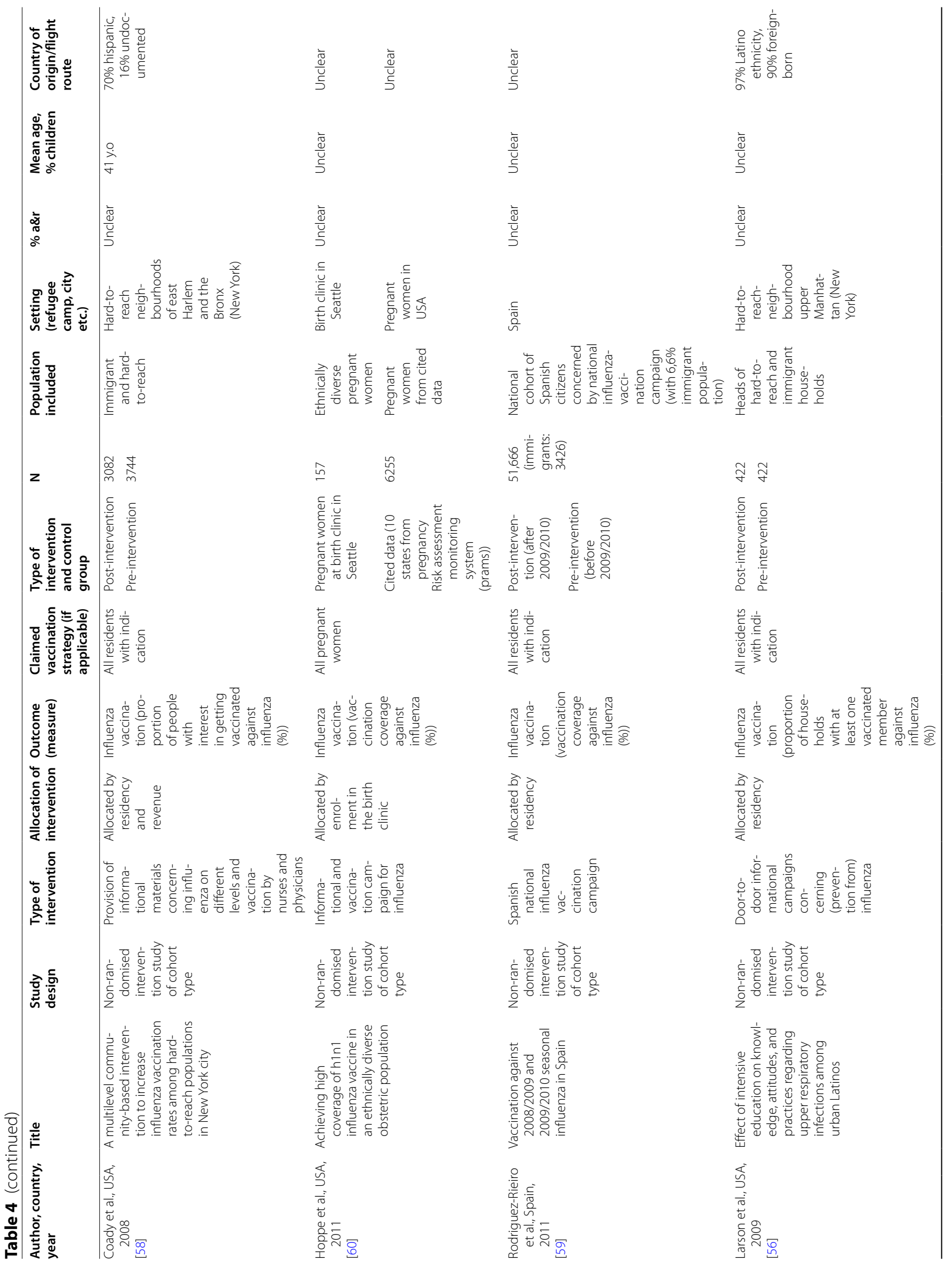




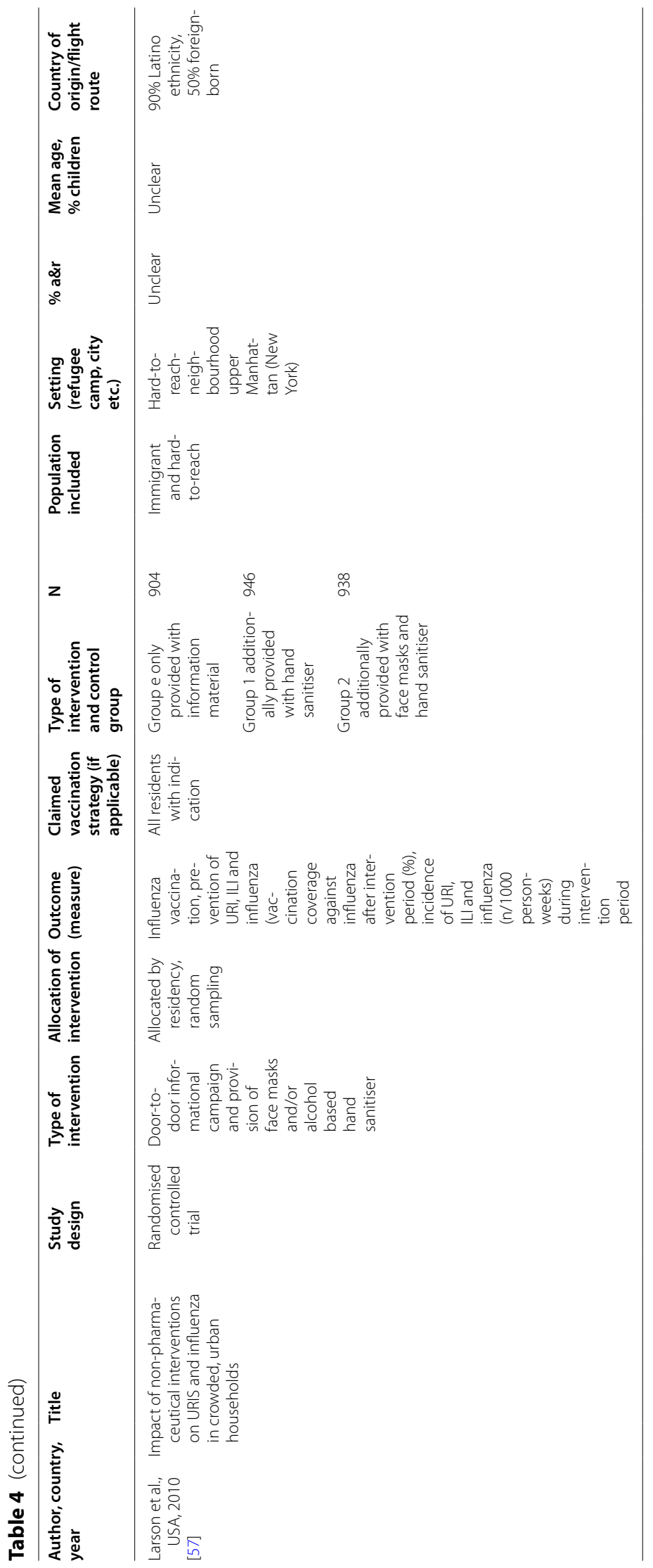


[67]. Keypersons are defined as trained persons from similar living conditions and ethnicities. In this study, they assisted in a door-to-door vaccination campaign in German hard-to-reach and broad-spectrum immigrant neighbourhoods with refugee proportions of about $30 \%$. The risk of receiving at least one dose of vaccination increased by $29 \%$, while the risk of receiving two doses increased by $52 \%$.

\section{Outbreak prevention}

In a Swiss interventional study, two varicella outbreak response strategies were evaluated in newly arrived refugees [69]. The first ("rapid") involved the isolation of index cases and serotesting and, if necessary, vaccination of people in the same housing facility. This was found to lower the proportion of infected persons from by $10 \%$ compared to an outbreak series in 2007 with no previously defined response strategy. The second ("general") response strategy involved the strict vaccination of all arriving refugees aged 15-39 years without a history of varicella, leading to no varicella infections in any refugee shelter.

\section{URI/ILI/Influenza prevention}

The previously-described randomised controlled trial by Larson et al. in hard-to-reach neighbourhoods also assessed rates of upper respiratory infections (URI), influenza and influenza-like illness (ILI) [57]. It was found that the URI rate/1000 person-weeks in the control group E (informational campaign only) was 35.38, in Group 1 (additional hand sanitiser) it was 29.06 and in Group 2 (hand sanitiser and face masks) it was 38.91. ILI rates/1000 person-weeks were 2.26 in Group E, 1.93 in Group 1, and 1.56 in Group 2. Influenza rates/1000 person-weeks were 0.52 in Group E, 0.60 in Group 1, and 0.49, 95\% CI: 0.32-0.73 in Group 2.

\section{Main evidence gaps}

The main evidence gaps include a lack of data on housing arrangement standards, interventions to reduce rates of bacterial pneumonia, and evidence for the efficacy of operating standards in refugee and immigrant health care and reception centres (Table 6).

\section{Risk of bias}

(See Table 7).

The most important sources of bias among studies targeting vaccination coverage of respiratory tract-related infections were confounding bias in seven $[56,58-60,66$, $68,70]$, reporting bias in six $[56,59,60,66,68,70]$ and bias due to the measurement of outcomes in 6 studies $[56,59,60,66,68,70]$. The most important non reported confounding factors were length of travel in seven [56$60,66,68-70]$, period of stay in seven $[56-60,66,70]$ and health literacy in seven studies [56, 58-60, 66-68]. The main source of bias among studies targeting prevention of upper respiratory tract infections, influenza-like illness, influenza and vaccination coverage for influenza was social desirability bias in three studies [56-58]. In two studies the risk of bias was rated as critical; one because of missing data [60], and the other mainly due to incorrect classification of interventions [59].

Across studies the heterogeneous outcome measures could be an important source of bias, especially among the studies on influenza vaccination uptake, as interest in being vaccinated [58] or the presence of a vaccinated person in a household [56] may not be valid measures of actual vaccination coverage $[57,60]$ in the examined population. Publication bias may also be an important source of bias, because with only two exceptions $[57,66]$, no negative intervention effect was described. Therefore, the findings regarding the overall effect of these interventions should be interpreted with caution [51] and evidence across all outcomes is evaluated as "low" following the GRADE approach.

Since the included studies have heterogeneous study designs, characteristics and outcome measures, no pooled analysis in the form of a meta-analysis was performed.

\section{Discussion}

\section{Key results}

In this systematic review of controlled studies, we collected evidence on interventions aiming to reduce morbidity or mortality from respiratory infections and to improve vaccination coverage among refugees and immigrants in hard-to-reach neighbourhoods. In six studies, we found evidence for the effectiveness of multilingual informational campaigns to increase the uptake of vaccination [56-58, 60, 67, 68].

There was limited evidence in one study that hand sanitiser reduced rates of upper respiratory infections and when provided together with face masks also the rates of influenza-like-illness in a hard to reach migrant neighbourhood [57].

To reduce secondary cases in outbreak situations, one study reported that in the case of vaccine-preventable diseases, general vaccination strategies implemented in refugees immediately after arrival have a large effect in reducing secondary cases. Evaluation of a positive history of infection or vaccination is sufficient, but serological testing after potential exposure is not necessary [69]. The hazard of outbreak situations is also lowered by this strategy. [69] 


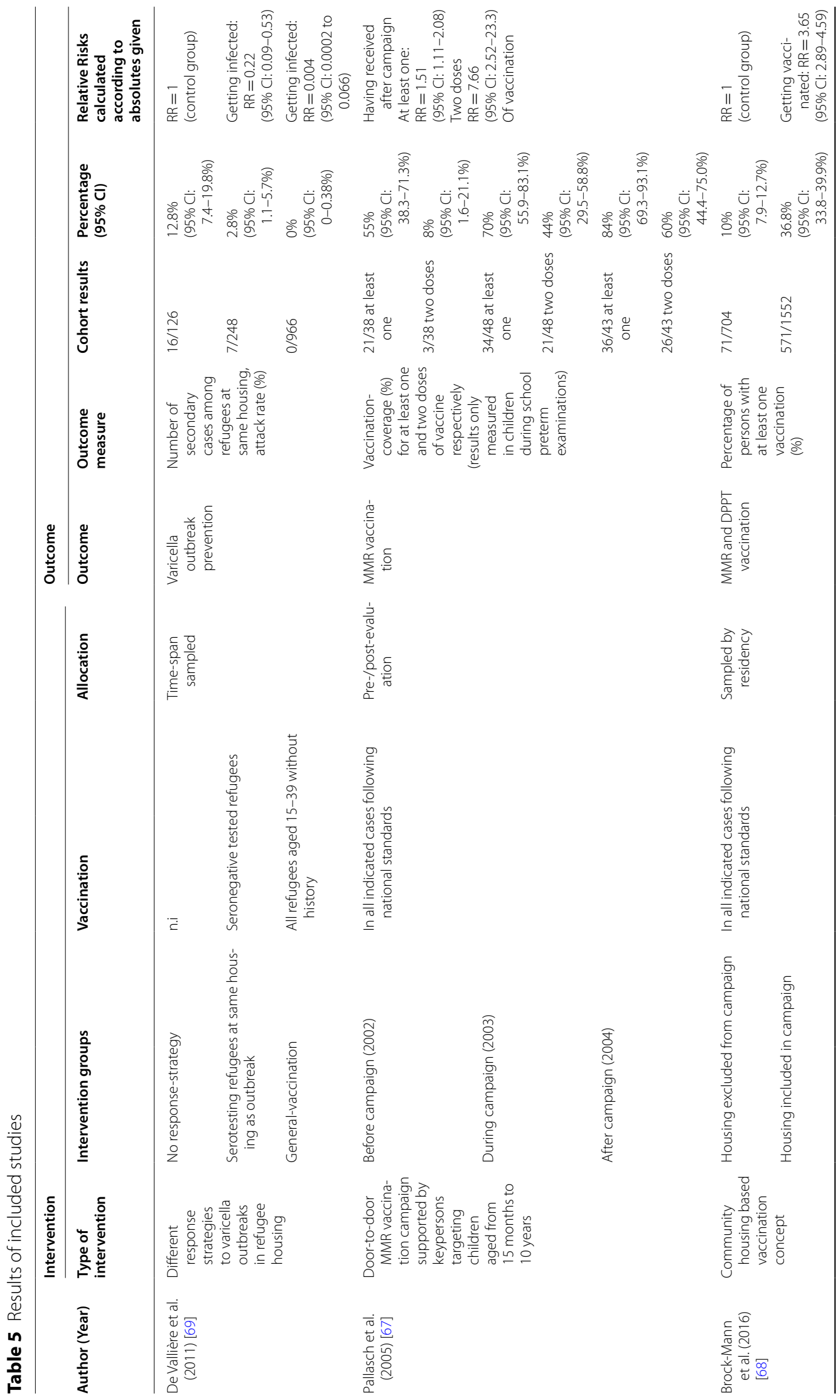




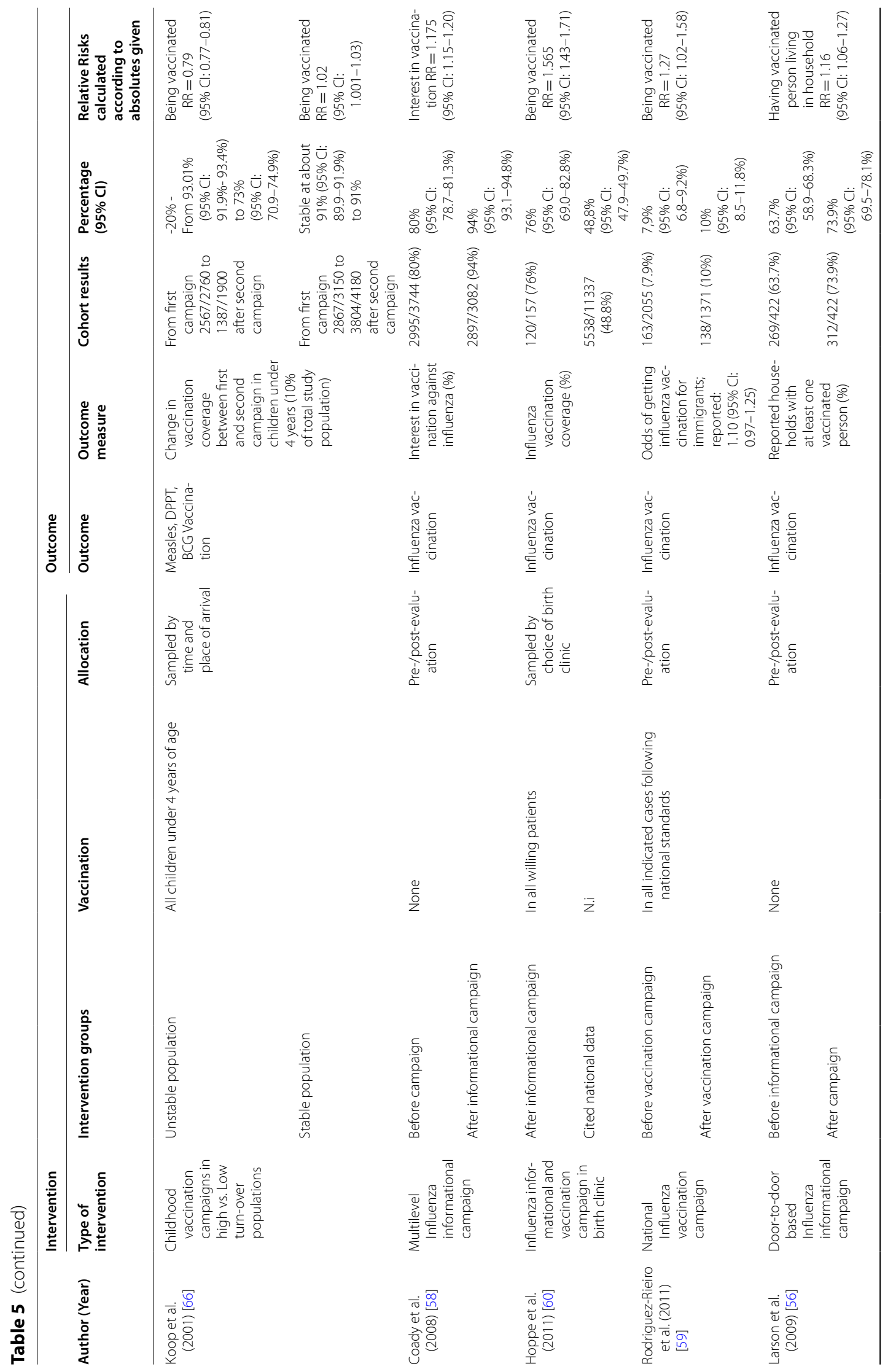




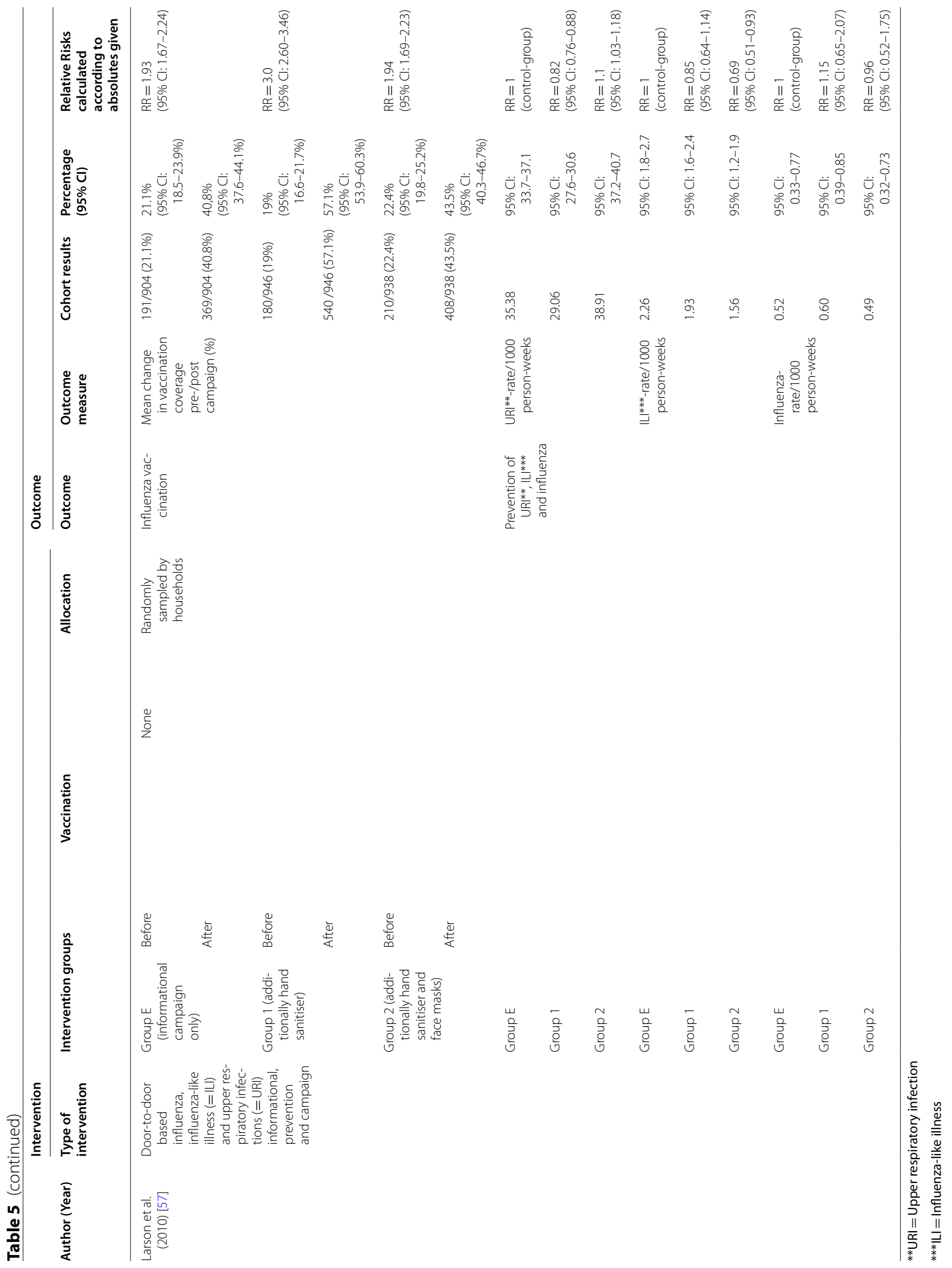


Table 6 Evidence gaps identified in this systematic review

\begin{tabular}{|c|c|c|c|c|c|}
\hline Outcome & Type of intervention & TB & Influenza & $\begin{array}{l}\text { Bacterial Pneumonia and lower } \\
\text { respiratory infections }\end{array}$ & Other \\
\hline \multirow[t]{5}{*}{ Reducing morbidity or mortality } & Information campaigns & + & - & - & - \\
\hline & Housing standards & - & - & - & - \\
\hline & Health literacy campaigns & + & - & - & - \\
\hline & Operational standards for health care & - & - & - & - \\
\hline & Personal Hygiene & + & + & - & + \\
\hline \multirow[t]{4}{*}{ Increasing vaccination coverage } & Information campaigns & + & + & - & + \\
\hline & Housing standards & - & - & - & - \\
\hline & Health literacy campaigns & + & + & - & - \\
\hline & Operational standards for health care & - & - & - & - \\
\hline
\end{tabular}

Table 7 Risk of bias assessment of included studies

\begin{tabular}{|c|c|c|c|c|c|c|c|c|}
\hline \multirow[b]{2}{*}{$\begin{array}{l}\text { Author } \\
\text { (year of } \\
\text { publication) }\end{array}$} & \multicolumn{8}{|c|}{ Using ROBINS-I-tool for non-randomised studies of cohort-type // Risk of bias due to: } \\
\hline & Confounding & $\begin{array}{l}\text { Selection of } \\
\text { participants }\end{array}$ & $\begin{array}{l}\text { Classification } \\
\text { of } \\
\text { interventions }\end{array}$ & $\begin{array}{l}\text { Deviation } \\
\text { from intended } \\
\text { interventions }\end{array}$ & Missing data & $\begin{array}{l}\text { Measurement } \\
\text { of outcomes }\end{array}$ & $\begin{array}{l}\text { Selection } \\
\text { of reported } \\
\text { result }\end{array}$ & $\begin{array}{l}\text { Overall } \\
\text { judgement }\end{array}$ \\
\hline $\begin{array}{l}\text { De Vallière } \\
\text { et al. (2011) } \\
\text { [69] }\end{array}$ & Low & Low & Low & Low & Low & Low & Low & Low \\
\hline $\begin{array}{l}\text { Pallasch et al. } \\
\text { (2005) [67] }\end{array}$ & Moderate & Moderate & Low & Low & Moderate & Moderate & Moderate & Moderate \\
\hline $\begin{array}{l}\text { Brockmann } \\
\text { et al. (2016) } \\
\text { [68] }\end{array}$ & Serious & Moderate & Low & Low & Moderate & Moderate & Serious & Serious \\
\hline $\begin{array}{l}\text { Koop et al. } \\
\text { (2001) [66] }\end{array}$ & Serious & Low & Moderate & Moderate & Low & Low & Serious & Serious \\
\hline $\begin{array}{l}\text { Coady et al. } \\
\text { (2008) [58] }\end{array}$ & Moderate & Low & Low & Low & Low & Moderate & Low & Moderate \\
\hline $\begin{array}{l}\text { Hoppe et al. } \\
\text { (2011) [60] }\end{array}$ & Serious & Serious & Low & Low & Critical & Serious & Serious & Critical \\
\hline $\begin{array}{l}\text { Rodriguez- } \\
\text { Rieiro et al. } \\
\text { (2011) [59] }\end{array}$ & Critical & Critical & Critical & Serious & Moderate & Moderate & Critical & Critical \\
\hline \multirow{3}{*}{$\begin{array}{l}\text { Larson et al. } \\
\text { (2009) [56] }\end{array}$} & Serious & Low & Moderate & Low & Serious & Serious & Serious & Serious \\
\hline & \multicolumn{8}{|c|}{ Using RoB 2.0 for cluster-randomised parallel group trials of intervention // Risk of bias due to } \\
\hline & $\begin{array}{l}\text { Randomisa- } \\
\text { tion process }\end{array}$ & $\begin{array}{l}\text { Timing of ident } \\
\text { recruitment } \\
\text { ticipants in re } \\
\text { of randomisa }\end{array}$ & $\begin{array}{l}\text { fication and } \\
\text { f individual par- } \\
\text { lation to timing } \\
\text { ion }\end{array}$ & $\begin{array}{l}\text { Deviations } \\
\text { from } \\
\text { intended } \\
\text { interventions }\end{array}$ & $\begin{array}{l}\text { Missing out- } \\
\text { come data }\end{array}$ & $\begin{array}{l}\text { Measurement } \\
\text { of outcomes }\end{array}$ & $\begin{array}{l}\text { Selection of } \\
\text { reported } \\
\text { result }\end{array}$ & $\begin{array}{l}\text { Overall judge- } \\
\text { ment }\end{array}$ \\
\hline $\begin{array}{l}\text { Larson et al. } \\
\text { (2010) [57] }\end{array}$ & Low [01-O4] & Low [01-O4] & & $\begin{array}{l}\text { Some concerns } \\
\text { [01-04] }\end{array}$ & Low [01-O4] & $\begin{array}{l}\text { Some concerns } \\
\text { [01-O4] }\end{array}$ & Low [01-04] & $\begin{array}{l}\text { Some concerns } \\
\text { [01-04] }\end{array}$ \\
\hline
\end{tabular}

\section{Evidence rarely reflected in international standards}

Five informational campaigns assessed in this review integrated the cultural and educational background of the targeted population [56-58, 60, 67], either by recruiting keypersons supporting the campaign staff [67], or by directly addressing common cultural myths about vaccinations $[57,58]$. The efficacy of this strategy is not currently reflected in national or international guidelines, but is congruent with evidence that informational campaigns, community und culturally-oriented health literacy interventions are effective in improving vaccination coverage in autochthonous populations [71-73].

Currently, only NICE recommends institutional health literacy interventions in immigrant populations, however 
these are not clearly defined. Other European guidelines for refugee and immigrant health care do not address this issue (Table 1).

European guidelines explicitly recommend against implementation of vaccination strategies at border crossings because informed consent is difficult to obtain [15]. However, a timely vaccination strategy has been shown to reduce the potential for outbreaks in particular for highly transmissible diseases [69]. Research is needed to determine the optimal strategies for obtaining informed consent in this situation [74-76].

No evidence could be found for interventions targeting housing facilities for refugees and immigrants, although they play an important role in the transmission and spreading of infectious diseases [15]. The effect of turnover of refugees and immigrants on vaccination coverage in refugee camps shows that it is easier to implement vaccination campaigns during the first months after arrival in more stable camps, but this study did not investigate overall housing conditions or number of housing units [66]. We did not find any controlled studies of interventions to reduce morbidity and mortality from relevant severe respiratory diseases such as bacterial pneumonia or interventions affecting the latency to diagnosis in airway infections.

\section{Limitations}

Migration status was not always clear for all participants in the identified studies. While most of the studies indicated the ethnic or geographical origin of the participants [56-58,60,67], only two primarily represented refugee populations $[66,69]$. However, interventions in the context of having fled from hardship, forced migration and life as a refugee are possibly presenting an important independent factor [5]. Countries of origin were not always clearly indicated, especially for Latin American and African populations. In addition, the heterogeneous outcome measures among the included studies made it difficult to obtain concrete effect estimates for refugee and immigrant populations. Some of the findings should be interpreted with caution due to methodological issues in several of the studies (see Table 7).

The countries of origin of refugees and immigrants have shifted in the last 10 years [77, 78], therefore we included a longer time-span to provide a broader overview and context in relation to refugee health.

\section{Conclusions}

Respiratory infections continue to be a major contributor to the poor health status of refugees and immigrants and currently interventions to lower this burden are not adequately reflected in national guidelines. This evidence synthesis shows that while there is some low-quality evidence for the effect and timing of multilingual vaccination campaigns that involve the community, there is little high-quality research on housing standards or operational standards needed to prevent respiratory infections in this population. Similar to other reviews of refugee and hard-to-reach populations for tuberculosis [29, 41], vaccine-preventable diseases [79] and respiratory infections [8], we conclude that it is important to follow community-involving principles in informational campaigns and that more controlled operational research is needed. New methods of ensuring informed consent for early vaccinations must also be established. This could allow immediate vaccinations upon arrival in order to reduce secondary infections in crowded living portals such as reception centres and mass housings. Also, for future research it is essential to indicate the political status of migrant study populations because the context of forced migration may present an important independent factor.

\section{Abbreviations}

Tb: Tuberculosis; VPD: Vaccine preventable diseases; AMR: Antimicrobial resistant pathogens; OECD: Organisation for Economic Co-operation and Development; EU: European Union; EEA: European Economic Area; ILI: Influenza-likeillness; URI: Upper respiratory infections.

\section{Supplementary Information}

The online version contains supplementary material available at https://doi. org/10.1186/s12879-021-06474-0.

Additional file 1. Included countries.

Additional file 2. Data extraction spreadsheet.

Additional file 3. Full search strategy.

\section{Acknowledgements}

Part of the results of this systematic review have been presented as an oral session at the 29th ECCMID in Amsterdam (April 2019). As previously stated, this systematic review was updated afterwards in October 2019.

\section{Authors' contributions}

Idea: $\mathrm{BL}, \mathrm{KS}, \mathrm{J}-\mathrm{FL}, \mathrm{MB}$. Conception and design: BL, MB, J-FL, KS. Data extraction and screening: J-FL, $A B, B L$. Interpretation of the findings: J-FL, $B L, J B, W K$, SR. First draft: J-FL, BL. Commented and revised first draft: MB, KS, AB, JB, SR, WK. All authors read and approved the final manuscript.

\section{Funding}

Open Access funding enabled and organized by Projekt DEAL.

\section{Availability of data and materials}

Not applicable. Full search strategy in Additional file 3. Data extraction spreadsheet in Additional file 2. Our full extraction dataset will only be available on request.

\section{Declarations}

Ethics approval and consent to participate Not applicabl. 


\section{Consent for publication}

Not applicable.

\section{Competing interests}

The authors declare that they have no competing interests.

\begin{abstract}
Author details
'Division of Infectious Diseases, Department of Medicine II, Medical Center and Faculty of Medicine, University of Freiburg, Hugstetter Straße 55, 79106 Freiburg im Breisgau, DE, Germany. ${ }^{2}$ Institute of Medical Biometry and Statistics, Faculty of Medicine and Medical Center, University of Freiburg, Freiburg im Breisgau, Germany. ${ }^{3}$ Department of Epidemiology, Helmholtz Centre for Infection Research, Inhoffenstr.7, 38124 Braunschweig, DE, Germany.
\end{abstract}

Received: 18 March 2020 Accepted: 26 July 2021

Published online: 26 August 2021

\section{References}

1. Office of the United Nations High Commissioner for Refugees. UNHCR Statistics-World in Numbers; 2017. https://popstats.unhcr.org/en/overv iew. Accessed 18 Jul 2018.

2. Morris MD, Popper ST, Rodwell TC, Brodine SK, Brouwer KC. Healthcare barriers of refugees post-resettlement. J Community Health. 2009;34(6):529-38. https://doi.org/10.1007/s10900-009-9175-3.

3. Avery R. Culture and medicine. Immigrant women's health: Infectious diseases - 4th article in a series of 5 articles exploring immigrant women's health. These articles are adapted from the book Immigrant Women's Health, published by Jossey-Bass, San Francisco, 1999. West J Med. 2001;175(3):208-11.

4. Pavli A, Maltezou H. Health problems of newly arrived migrants and refugees in Europe [Review]. J Travel Med. 2017. https://doi.org/10.1093/ $\mathrm{jtm} / \mathrm{tax} 016$

5. Eiset $\mathrm{AH}$, Wejse $\mathrm{C}$. Review of infectious diseases in refugees and asylum seekers-current status and going forward. Public Health Rev. 2017;38:22. https://doi.org/10.1186/s40985-017-0065-4.

6. Nellums LB, Thompson $\mathrm{H}$, Holmes A, et al. Antimicrobial resistance among migrants in Europe: a systematic review and meta-analysis. Lancet Infect Dis. 2018;18(7):796-811. https://doi.org/10.1016/S14733099(18)30219-6.

7. Hargreaves S, Lonnroth K, Nellums LB, et al. Multidrug-resistant tuberculosis and migration to Europe [Review]. Clin Microbiol Infect. 2017;23(3):141-6. https://doi.org/10.1016/j.cmi.2016.09.009.

8. Bellos A, Mulholland K, O'Brien KL, Qazi SA, Gayer M, Checchi F. The burden of acute respiratory infections in crisis-affected populations: a systematic review. Confl Health. 2010;4:3. https://doi.org/10.1186/ 1752-1505-4-3.

9. Mipatrini D, Stefanelli P, Severoni S, Rezza G. Vaccinations in migrants and refugees: a challenge for European health systems. A systematic review of current scientific evidence [Review]. Pathog Glob Health. 2017;111(2):59_ 68. https://doi.org/10.1080/20477724.2017.1281374.

10. Olivan GG. Assessing the health and nutritional status of illegal immigrant adolescents from Maghreb. Anales de Pediatría. 2000;53(1):17-20.

11. Pohl C, Mack I, Schmitz T, Ritz N. The spectrum of care for pediatric refugees and asylum seekers at a tertiary health care facility in Switzerland in 2015. Eur J Pediatr. 2017;176(12):1681-7. https://doi.org/10.1007/ s00431-017-3014-9.

12. Alberer M, Wendeborn M, Loscher T, Seilmaier M. Spectrum of diseases occurring in refugees and asylum seekers: Data from three different medical institutions in the Munich area from 2014 and 2015] [German]. Dtsch Med Wochenschr. 2016;141(1):e8-15. https://doi.org/10. 1055/s-0041-106907.

13. Australian Government Department of Health. The Australian Immunisation Handbook; 2017. https://immunisationhandbook.health.gov.au/ resources/publications/vaccination-for-migrants-refugees-and-people-seeking-asylum\#; https://www.asid.net.au/documents/item/1225. Accessed 30 May 2018.

14. Centers for Disease Control and Prevention. Guidelines for pre-departure and post-arrival medical screening and treatment of U.S.-bound refugees;
2013. Available from: https://www.cdc.gov/immigrantrefugeehealth/ guidelines/refugee-guidelines.html. Accessed 18 July 2018.

15. Suk J, Espinosa L, Silvia produced by the Italian Institute of Public Health. Handbook on using the ECDC preparedness checklist tool to strengthen preparedness against communicable disease outbreaks at migrant reception/detention centres: Technical document; 2016. Available from: https://www.ecdc.europa.eu/sites/default/files/media/en/publications/ Publications/preparedness-checklist-migrant-centres-tool.pdf. Accessed 17 July 2018.

16. National Advisory Committee on Immunization (NACl), Committee to Advise on Tropical Medicine and Travel (CATMAT). Canadian Immunization Guide; 2015. https://www.canada.ca/en/public-health/services/publi cations/healthy-living/canadian-immunization-guide-part-3-vaccinationspecific-populations/page-10-immunization-persons-newcanada.html\# p3c9a4. Accessed 17 July 2018.

17. National Institute for Health Care Excellence. Migrant health guide: countries A to Z: Advice and guidance on the health needs of migrant patients for healthcare practitioners: NICE; 2017.https://www.gov.uk/government/ collections/migrant-health-guide-countries-a-to-z. Accessed 18 July 2018.

18. Robert-Koch-Institut. Konzept zur Umsetzung frühzeitiger Impfungen bei Asylsuchenden nach Ankunft in Deutschland. Epidemiologisches Bulletin: RKI-Bib1 (Robert Koch-Institut); 2015. https://www.rki.de/DE/Conte nt/Infekt/EpidBull/Archiv/2015/Ausgaben/41_15.pdf?_blob=publicatio nFile. https://doi.org/10.17886/EpiBull-2015-011.4.

19. Robert-Koch-Institut. Vorscreening und Erstaufnahmeuntersuchung für Asylsuchende; 2015. Available from: https://www.rki.de/DE/Content/ GesundAZ/A/Asylsuchende/Erstaufnahme/Erstaufnahmeuntersuchung. pdf?_blob=publicationFile. Accessed 15 July 2018

20. Bernhard S, Büttcher M, Heininger U, Ratnam S, Relly $C$, Trück J, Wagner N, Zucol F, Berger C, Ritz N. Guidance for testing and preventing infections and updating immunisations in asymptomatic refugee children and adolescents in Switzerland; 2016. Available from: https://www.researchga te.net/publication/299609687_Guidance_for_testing_and_preventing_ infections_and_updating_immunisations_in_asymptomatic_refugee_ children_and_adolescents_in_Switzerland. Accessed 19 July 2018.

21. World-Health-Organization, Regional Office for Europe. WHO-UNHCRUNICEF joint technical guidance: general principles of vaccination of refugees, asylum-seekers and migrants in the WHO European Region: World-Health-Organization, Regional Office for Europe; 2015. Avalaible from: https://www.euro.who.int/en/health-topics/health-determinants/ migration-andhealth/news/news/2015/11/who,-unicef-and-unhcr-callfor-equitable-access-to-vaccines-for-refugees-and-migrants/who-unhcrunicef-joint-technical-guidance-general-principles-of-vaccination-ofref ugees,-asylum-seekers-and-migrants-in-the-who-european-region. Accessed 18 July 2018.

22. Hvass AMF, Wejse C. Systematic health screening of refugees after resettlement in recipient countries: a scoping review. Ann Hum Biol. 2017;017:1-9. https://doi.org/10.1080/03014460.2017.1330897.

23. Seedat F, Hargreaves S, Nellums LB, Ouyang J, Brown M, Friedland JS. How effective are approaches to migrant screening for infectious diseases in Europe? A systematic review. Lancet Infect Dis. 2018. https://doi.org/10. 1016/S1473-3099(18)30117-8.

24. Bozorgmehr K, Wahedi K, Noest S, Szecsenyi J, Razum O. Infectious disease screening in asylum seekers: range, coverage and economic evaluation in Germany, 2015. Euro Surveill. 2017. https://doi.org/10.2807/ 1560-7917.ES.2017.22.40.16-00677].

25. Dasgupta K, Menzies D. Cost-effectiveness of tuberculosis control strategies among immigrants and refugees [Review] [78 refs]. Eur Respir J. 2005;25(6):1107-16. https://doi.org/10.1183/09031936.05.00074004.

26. Aldridge RW, Yates TA, Zenner D, White PJ, Bubakar IA, Hayward AC. Pre-entry screening programmes for tuberculosis in migrants to lowincidence countries: a systematic review and meta-analysis. Lancet Infect Dis . 2014;14(12):1240-9. https://doi.org/10.1016/S1473-3099(14)70966-1.

27. Campbell JR, Krot J, Elwood K, Cook V, Marra F. A systematic review on TST and IGRA tests used for diagnosis of LTBI in immigrants [Review]. Mol Diagn Ther. 2015;19(1):9-24. https://doi.org/10.1007/s40291-014-0125-0.

28. Razum O, Bunte A, Gilsdorf A, Ziese T, Bozorgmehr K. Gesundheitsversorgung von Geflüchteten: Zu gesicherten Daten kommen. Deutsches Ärzteblatt. 2016;113(4). Available from: https://www.aerzteblatt.de/pdf/ 113/4/a130.pdf. Accessed 01 Aug 2018. 
29. Heuvelings CC, de Vries SG, Greve PF, et al. Effectiveness of interventions for diagnosis and treatment of tuberculosis in hard-to-reach populations in countries of low and medium tuberculosis incidence: a systematic review. Lancet Infect Dis. 2017;17(5):e144-58. https://doi.org/10.1016/ S1473-3099(16)30532-1.

30. Pareek M, Greenaway C, Noori T, Munoz J, Zenner D. The impact of migration on tuberculosis epidemiology and control in high-income countries: a review [Review]. BMC Med. 2016;14:48. https://doi.org/10.1186/ s12916-016-0595-5.

31. Adams KM, Gardiner LD, Assefi N. Healthcare challenges from the developing world: Post-immigration refugee medicine. BMJ. 2004;328(7455):1548-52. https://doi.org/10.1136/bmj.328.7455.1548.

32. Jensen NK, Norredam M, Draebel T, Bogic M, Priebe S, Krasnik A. Providing medical care for undocumented migrants in Denmark: What are the challenges for health professionals? BMC Health Serv Res. 2011. https://doi. org/10.1186/1472-6963-11-154.

33. McCarthy AE, Weld LH, Barnett ED, et al. Spectrum of illness in international migrants seen at GeoSentinel clinics in 1997-2009, part 2: migrants resettled internationally and evaluated for specific health concerns. Clin Infect Dis. 2013:56(7):925-33. https://doi.org/10.1093/cid/cis1016.

34. Robert Koch-Institut. Gesundheit und gesundheitliche Versorgung von Asylsuchenden und Flüchtlingen in Deutschland. RKI-Bib1 (Robert KochInstitut); 2017. Available from: https://edoc.rki.de/handle/176904/2579. Acessed 29 July 2018.

35. Figueira M, Christiansen D, Barnett ED. Cost-effectiveness of serotesting compared with universal immunization for varicella in refugee children from six geographic regions. J Travel Med. 2003;10(4):203-7. https://doi. org/10.2310/7060.2003.40545.

36. Moher D, Liberati A, Tetzlaff J, Altman DG. Preferred reporting items for systematic reviews and meta-analyses: The PRISMA statement. BMJ. 2009;339:b2535.

37. Higgins JPT, editor. Cochrane handbook for systematic reviews of interventions. Oxford: Wiley-Blackwell; 2011. (Reprint).

38. Green S. Cochrane handbook for systematic reviews of interventions. Oxford: Wiley-Blackwell; 2009. (Reprint with Corr)

39. Lambert J-F, Boeker M, Kennett A, Lange B. Effects of early interventions concerning prevention, management and therapy of respiratory tract infections in refugees and asylum-seekers in membership-countries of the OECD, EU, EEA and EU-applicant countries: PROSPERO 2018 CRD42018074338; 2018. http://www.crd.york.ac.uk/PROSPERO/display_ record.php?ID=CRD42018074338. Accessed 09 July 2018.

40. Convention and Protocol Relating to the Status of Refugees $1951 \mathrm{Jul} 28$ Available from: https://www.unhcr.org/3b66c2aa10.html. Accessed 27 July 2018.

41. de Vries SG, Cremers AL, Heuvelings CC, et al. Barriers and facilitators to the uptake of tuberculosis diagnostic and treatment services by hard-to-reach populations in countries of low and medium tuberculosis incidence: a systematic review of qualitative literature [Review]. Lancet Infect Dis. 2017;17(5):e128-43. https://doi.org/10.1016/S1473-3099(16) 30531-X.

42. OECD - Organisation for Economic Co-operation and Development. Convention on the Organisation for Economic Co-operation and Development; 1960. http://www.oecd.org/general/conventionontheorganisati onforeconomicco-operationanddevelopment.htm. Accessed 27 Jul 2018.

43. Woyke W, editor. Handwörterbuch Internationale Politik. 7. aktualisierte. Wiesbaden: VS Verlag für Sozialwissenschaften; 1998.

44. Hrbek R. Europäische Union. In: Woyke W, editor. Handwörterbuch Internationale Politik. 7. aktualisierte. Wiesbaden: VS Verlag für Sozialwissenschaften; 1998. p. 81-97.

45. European Free Trade Association. Agreement on the European Economic Area; 1994. http://www.efta.int/sites/default/files/documents/legal-texts/ eea/the-eea-agreement/Main\%20Text\%20of\%20the\%20Agreement/ EEAagreement.pdf. Accessed 27 Jul 2018.

46. European Commission. Enlargement: candidate countries and potential candidates; 2018. http://ec.europa.eu/environment/enlarg/candidates. htm. Accessed 27 Jul 2018.

47. Lefebvre C, Manheimer E, Glanville J. Searching for Studies. In: Higgins JPT, editor. Cochrane handbook for systematic reviews of interventions. Chichester: Wiley-Blackwell; 2008. p. 95-150.
48. Universitätsklinikum Freiburg / Deutsches Cochrane Zentrum. Manual Systematische Literaturrecherche für die Erstellung von Leitlinien. Germany: Universität Freiburg; 2013.

49. Sterne JA, Hernán MA, Reeves BC, et al. ROBINS-I: a tool for assessing risk of bias in non-randomised studies of interventions. BMJ. 2016;355:i4919.

50. Higgins JPT, Sterne JAC, Savović J, Page MJ, Hróbjartsson A, Boutron I, Reeves $B$, Eldridge $S$. A revised tool for assessing risk of bias in randomized trials. Cochrane Database Syst Rev. 2016;3:29-31.

51. Guyatt GH, Oxman AD, Vist G, et al. GRADE guidelines: 4. Rating the quality of evidence-study limitations (risk of bias). J Clin Epidemiol. 2011;64(4):407-15. https://doi.org/10.1016/j.jclinepi.2010.07.017.

52. Andrews J, Guyatt G, Oxman AD, et al. GRADE guidelines: 14. Going from evidence to recommendations: the significance and presentation of recommendations. J Clin Epidemiol. 2013;66(7):719-25. https://doi.org/ 10.1016/j.jclinepi.2012.03.013.

53. Balshem $H$, Helfand $M$, Schünemann $H J$, et al. GRADE guidelines: 3 . Rating the quality of evidence. J Clin Epidemiol. 2011;64(4):401-6. https://doi. org/10.1016/j.jclinepi.2010.07.015.

54. Guyatt G, Oxman AD, Akl EA, et al. GRADE guidelines: 1. IntroductionGRADE evidence profiles and summary of findings tables. J Clin Epidemiol. 2011;64(4):383-94. https://doi.org/10.1016/j.jclinepi.2010.04.026.

55. Guyatt GH, Oxman AD, Kunz R, et al. GRADE guidelines: 2. Framing the question and deciding on important outcomes. J Clin Epidemiol. 2011;64(4):395-400. https://doi.org/10.1016/j.jclinepi.2010.09.012.

56. Larson EL, Ferng YH, McLoughlin JW, Wang S, Morse SS. Effect of intensive education on knowledge, attitudes, and practices regarding upper respiratory infections among urban Latinos. Nurs Res. 2009;58(3):150-7. https://doi.org/10.1097/NNR.0b013e3181a30951.

57. Larson EL, Ferng Y-H, Wong-McLoughlin J, Wang S, Haber M, Morse SS. Impact of non-pharmaceutical interventions on URIs and influenza in crowded, urban households. Public Health Rep. 2010;125(2):178-91. https://doi.org/10.1177/003335491012500206.

58. Coady MH, Galea S, Blaney S, et al. Project VIVA: A multilevel communitybased intervention to increase influenza vaccination rates among hard-to-reach populations in New York City. Am J Public Health. 2008;98(7):1314-21. https://doi.org/10.2105/AJPH.2007.119586.

59. Rodríguez-Rieiro C, Hernández-Barrera V, Carrasco-Garrido P, de Andres AL, Jiménez-García R. Vaccination against 2008/2009 and 2009/2010 seasonal influenza in Spain: coverage among high risk subjects, HCWs, immigrants and time trends from the 2005/2006 campaign. Vaccine. 2011;29(35):6029-34. https://doi.org/10.1016/j.vaccine.2011.06.030.

60. Hoppe KK, Eckert LO. Achieving high coverage of H1N1 influenza vaccine in an ethnically diverse obstetric population: Success of a multifaceted approach. Infect Dis Obstet Gynecol. 2011;011: 746214. https://doi.org/ 10.1155/2011/746214.

61. Ahluwalia IB, Jamieson DJ, Rasmussen SA, D'Angelo D, Goodman D, Kim $\mathrm{H}$. Correlates of seasonal influenza vaccine coverage among pregnant women in Georgia and Rhode Island. Obstet Gynecol. 2010;116(4):949_ 55. https://doi.org/10.1097/AOG.0b013e3181f1039f.

62. Centers for Disease Control and Prevention. Use of influenza A ( $\mathrm{H} 1 \mathrm{~N} 1)$ 2009 monovalent vaccine: recommendations of the Advisory Committee on Immunization Practices (ACIP); 2009. Available from: https://pubmed. ncbi.nlm.nih.gov/19713882/.

63. Centers for Disease Control and Prevention. Prevention and control of influenza with vaccines: recommendations of the Advisory Committee on Immunization Practices (ACIP); 2010. https://www.cdc.gov/MMWR/ PREVIEW/MMWRHTML/rr5908a1.htm.

64. Centers for Disease Control and Prevention. Prevention and control of influenza with vaccines: recommendations of the Advisory Committee on Immunization Practices (ACIP); 2010. https://www.cdc.gov/MMWR/ PREVIEW/MMWRHTML/rr5908a1.htm. Accessed 24 July 2018.

65. Lu PJ, Ding H, Euler GL, et al. State-specific influenza A (H1N1) 2009 monovalent vaccination coverage-United States, October 2009-January 2010. MMWR. 2010;59(12):363-8.

66. Koop BM. Results of the expanded program on immunization in the Macedonia refugee camps. Am J Public Health. 2001;91(10):1656-9. https:// doi.org/10.2105/AJPH.91.10.1656.

67. Pallasch G, Salman R, Hartwig C. [Improvement of protection given by vaccination for socially underprivileged groups on the basis of "key persons approach" - results of an intervention based on cultural and language aspects for children of immigrants in Altlander Viertel provided 
by the Health Department of Stade] [German]. Gesundheitswesen. 2005;67(1):33-8. https://doi.org/10.1055/s-2004-813912.

68. Brockmann SO, Wjst S, Zelmer U, et al. ÖGD-Initiative zur Verbesserung der Durchimpfung bei Asylsuchenden. Bundesgesundheitsblatt . 2016;59(5):592-8. https://doi.org/10.1007/s00103-016-2335-6.

69. de Valliere S, Cani N, Grossenbacher M, Puig F, Masserey E, Bodenmann P. Comparison of two strategies to prevent varicella outbreaks in housing facilities for asylum seekers. Int J Infect Dis. 2011;15(10):e716-21. https:// doi.org/10.1016/j.ijid.2011.06.001.

70. Pallasch G, Salman R, Hartwig C. Verbesserung des Impfschutzes für sozial benachteiligte Gruppen unter Mitarbeit von Vertrauenspersonen - Ergebnisse einer kultur- und sprachsensiblen Intervention des Gesundheitsamtes Stade und des Ethno-Medizinischen Zentrums für Migrantenkinder im Altländer Viertel. Das Gesundheitswesen. 2005;67(1):33-8. https://doi.org/10.1055/s-2004-813912.

71. Jaca A, Mathebula L, Iweze A, Pienaar E, Wiysonge CS. A systematic review of strategies for reducing missed opportunities for vaccination. Vaccine. 2018;36(21):2921-7. https://doi.org/10.1016/j.vaccine.2018.04.028.

72. Lukusa LA, Ndze VN, Mbeye NM, Wiysonge CS. A systematic review and meta-analysis of the effects of educating parents on the benefits and schedules of childhood vaccinations in low and middle-income countries. Hum Vaccin Immunother. 2018. https://doi.org/10.1080/21645515. 2018.1457931.

73. Deardorff KV, Rubin Means A, Ásbjörnsdóttir KH, Walson J. Strategies to improve treatment coverage in community-based public health programs: a systematic review of the literature. PLoS Negl Trop Dis. 2018;12(2): e0006211. https://doi.org/10.1371/journal.pntd.0006211.

74. Boulos D, Morand E, Foo M, et al. Acceptability of opt-out consent in a hospital patient population. Intern Med J. 2018;48(1):84-7. https://doi. org/10.1111/imj.13666.

75. Makhoul J, Chehab RF, Shaito Z, Sibai AM. A scoping review of reporting "Ethical Research Practices" in research conducted among refugees and war-affected populations in the Arab world. BMC Med Ethics. 2018;19(1):36. https://doi.org/10.1186/s12910-018-0277-2.

76. Vellinga A, Cormican M, Hanahoe B, Bennett K, Murphy AW. Opt-out as an acceptable method of obtaining consent in medical research: a short report. BMC Med Res Methodol. 2011;11:40. https://doi.org/10.1186/ 1471-2288-11-40.

77. Bundesamt für Migration und Flüchtlinge. Migration, Asyl und Integration: in Zahlen: interior ministry of Bundesrepublik Deutschland; 2005. http://www.bamf.de/SharedDocs/Anlagen/DE/Publikationen/Brosc hueren/broschuere-statistik-2005.pdf?_blob=publicationFile. Accessed 27 Jul 2018.

78. Bundesamt für Migration und Flüchtlinge. Aktuelle Zahlen zu Asyl: interior ministry of Bundesrepublik Deutschland; 2018. Available from: https:/de.statista.com/statistik/daten/studie/154287/umfrage/haupt herkunftslaender-von-asylbewerbern/. Accessed 24 July 2018.

79. Crocker-Buque T, Mindra G, Duncan R, Mounier-Jack S. Immunization, urbanization and slums - a systematic review of factors and interventions. BMC Public Health. 2017. https://doi.org/10.1186/ s1 2889-017-4473-7.

80. Pottie K, Mayhew AD, Morton RL, et al. Prevention and assessment of infectious diseases among children and adult migrants arriving to the European Union/European Economic Association: a protocol for a suite of systematic reviews for public health and health systems. BMJ Open. 2017;7(9): e014608. https://doi.org/10.1136/bmjopen-2016-014608.

81. Chernet A, Utzinger J, Sydow V, et al. Prevalence rates of six selected infectious diseases among African migrants and refugees: a systematic review and meta-analysis. Eur J Clin Microbiol Infect Dis. 2018;37(4):60519. https://doi.org/10.1007/s10096-017-3126-1.

\section{Publisher's Note}

Springer Nature remains neutral with regard to jurisdictional claims in published maps and institutional affiliations.
Ready to submit your research? Choose BMC and benefit from:

- fast, convenient online submission

- thorough peer review by experienced researchers in your field

- rapid publication on acceptance

- support for research data, including large and complex data types

- gold Open Access which fosters wider collaboration and increased citations

- maximum visibility for your research: over 100M website views per year

At BMC, research is always in progress.

Learn more biomedcentral.com/submissions 